\title{
„...vonkoncom vždy je pekné znovu začínat'..."1 Pedagogické pôsobenie Alžbety Güntherovej-Mayerovej (1905 - 1973) na Univerzite Komenského v Bratislave
}

\author{
Katarína KOLBIARZ CHMELINOVÁ
}

\begin{abstract}
This article is an in-depth probe into A. Güntherová-Mayerová's pedagogical activities at the Comenius University in Bratislava, which affected an entire generation of our art historians. It based on the summarizing and verifying of known, but especially new information acquired through the study of various archive sources. It strives to provide answers to questions arising from our existing knowledge about the aforementioned issues starting with the clarification of the true extent of her work since the second half of the 1930s until 1961. The character and extent of her teaching is presented against the historical background of our university instruction of art history. Emphasis is placed on the crucial period of her university work in the socialist era of the Czechoslovak Republic in the1950s with the significant professionalization of education in the discipline, which we have partly inherited today, accompanied by its strong political deformation. Unfortunately, her forced dismissal from the university in 1961 meant the loss of the universal expert with vision, ability and a team capable of building a strong art-historical scientific-educational institute.
\end{abstract}

Keywords: Alžbeta Güntherová-Mayerová, Comenius University, Slovak University, art history, Sovietization

Docentku Alžbetu Güntherovú-Mayerovú, jednu zo zakladajúcich osobností slovenského dejepisu umenia, zdanlivo netreba predstavovat'. (obr. 1) Jej meno je vd'aka enormnému rozsahu a významu práce neprehliadnutel'né a spolu s jej t’ažkým osu-

1 KAHOUN, K.: Úvodné slovo. In: Stretnutie so životom a dielom Alžbety Güntherovej-Mayerovej. Zborník príspevkov z kolokvia konaného 27. novembra 2003 v Bratislave. Ed. HERUCOVÁ, M. Bratislava 2003, s. 8 .

2 Alžbeta Güntherová-Mayerová. In: 100 rokov Mestského múzea v Bratislave 1868 - 1968. Bratislava 1968, s. 305-309. SEDMÍK, K.: In memoriam Alžbety Güntherové. In: Umění a remesla, 16, 1973, č. 4, s. 75. VACULÍK, K.: Doc. PhDr. Alžbeta Güntherová-Mayerová (1905 - 1973). In: Umèní, časopis Ústavu teorie a dějin umění Československé akademie věd, 22, 1974, s. 356. LUXOVÁ, V.: Doc. PhDr. Alžbeta dom bolo priblížené odbornej i laickej verejnosti viackrát. Počínajúc nekrológmi a jej skorým obsiahlejším odborným profilom od Viery Luxovej v ARSe $(1975-79)^{2}$ po rôzne parciálne reflexie jej pôsobenia osvetl'ujúce vybrané časti práce Güntherovej-Maye-

Güntherová-Mayerová (1905 - 1973). In: ARS, roč. 9-10, 1975 - 1976, č. 1-4, s. 329-332. Stručne spolu s osobnou reflexiou publikovala k výročiu úmrtia Güntherovej-Mayerovej: KUBÍKOVÁ, K.: Alžbeta Güntherová-Mayerová. In: Výtvarný život, 28, 1983, č. 1, s. 18-19. Alžbeta Güntherová-Mayerová. In: Slovenský biografický slovník, zv. II. Martin 1987, s. 244. Okrem nekrológov a spomienkových profilov najmä príspevky v zborníku HERUCOVÁ (ed.) 2003, c. d. (v pozn. 1) a štyri kratšie texty v Monument revue, 2, 2013, č. 1 - čast' Monumentológia, s. 20-34; d’alej niekol'ko prác J. Barcziho - BARCZI, J: Alžbeta Güntherová-Mayerová a Vysoká škola výtvarných umení. In: http://www.soga.sk/ 
rovej na rôznych miestach (Martin, Betliar) či v niektorých inštitúciách (napríklad v Mestskom múzeu). Napokon zo spracovania jej osobného fondu z Archívu výtvarného umenia Slovenskej národnej galérie v Bratislave vzišiel i celistvejší pohl'ad na jej život a prácu. ${ }^{3} \mathrm{~A}$ vd’aka priekopníckym prácam Jána Bakoša a Ingrid Ciulisovej je dnes zrejmá i jej nezamenitel'ná pozícia v celkovom kontexte umenovedného vývoja na Slovensku. ${ }^{4}$ Rozsah a význam jej pôsobenia však zd'aleka neboli vyčerpané, ako to spolu s poukazom na nesúlad niektorých publikovaných údajov nedávno potvrdil bližší pohlad na univerzitné dejiny umenia $\mathrm{v}$ Bratislave, $\mathrm{v}$ ktorých rovnako zohrala nemalú rolu. ${ }^{5}$

Trojjazyčným prostredím rodného Prešporka (Bratislavy) sformovaná Alžbeta Mária Therezia Mayerová, v rodinnom kruhu prezývaná Lili, vstúpila po maturite do kontaktu s umením najskôr v jeho praktickej podobe. V roku 1924 sa zapísala na štátom podporovanú súkromnú maliarsku školu Gustáva Mallého v Bratislave, kde mala možnost' spoznat' Ludovíta Fullu, Jána Želibského, Jána Mudrocha, či Kolomana Sokola. Na poli úžitkovej grafiky bola

aukcie-obrazy-diela-umenie-starozitnosti/blogy/julius-barczi/alzbeta-guntherova-mayerova-a-vysoka-skola-vytvarnych-umeni (10.11.2019); text skrátene publikovaný Idem: Alžbeta Güntherová-Mayerová. In: Vysoká škola výtvarných umeni v Bratislave: 1949-2009: 60 rokov. Ed.: RUSINA, I. Bratislava 2009, s. 197. Pozri tiež Po stopách výtvarnej minulosti Slovenska : výber z diela Alžbety Güntherovej-Mayerovej. Ed.: PETROVÁ-PLESKOTOVÁ, A. Bratislava 1995.

3 ŠEFČÁKOVÁ, E.: Alžbeta Güntherová-Mayerová - život a dielo. In: HERUCOVÁ (ed.) 2003, c. d. (v pozn. 1), s. 13-47.

4 BAKOŠ, J.: Príbeh zakliatej vednej disciplíny. Seminár dejín umenia na Bratislavskej univerzite. In: Pocta Václavovi Menclovi. Zbornik stúdii k otázkam interpretácie stredoeurópskeho umenia. Bratislava 2000, s. 9-18. Tiež Idem: Situácia dejepisu umenia na Slovensku. Bratislava 1984, s. 66-78. Idem: Štyri trasy metodológie dejín umenia. Bratislava 2000, s. 61-62, 65, CIULISOVÁ, I.: Dejepis umenia na Slovensku. Vybrané kapitoly, Bratislava 2011, s. 17-18, 39-40, 53-89, 115-119.

$595+$ Dejiny umenia na Univerzite Komenského v Bratislave. Ed. KOLBIARZ CHMELINOVÁ, K. - BEŇOVÁ, K. Bratislava 2018. KOLBIARZ CHMELINOVÁ, K.: Pedagogické pôsobenie Alžbety Güntherovej-Mayerovej (1905-1973) na Univerzite Komenského, verejná prednáška z cyklu k dejinám Katedry dejín výtvarného umenia Univerzity Komenského v Bratislave z 20.3. 2019. Táto štúdia, ukončená na začiatku roku 2020, je jej prepracovanou v druhej polovici 20. rokov 20. storočia pomerne úspešná. Jej návrhy našli uplatnenie v Bratislave i mimo nej vo firmách ako tlačiareň Wigand, módny dom Tausky či Dedeo a Löwy, údenárstvo Klicha a synovia, Meinl Chocolate, alebo Tatra auto Praha a v roku 1929 vyhrala medzinárodnú sút’až na plagát pre Bat'ove závody. ${ }^{6} \mathrm{~V}$ zlínskom Bat'ovom závode však pracovne pôsobila len krátko a $z$ rodinných dôvodov sa vrátila do Bratislavy. Vo februári 1930 nastúpila do zamestnania vo Vedeckých ústavoch mesta Bratislava, ktoré spravovali aj zbierky Mestského múzea. V ňom až do roku 1940, v nadväznosti na Gizelu Weyde-Leveke a v spolupráci s Ol'gou Wagnerovou, katalogizovala zbierky, skoncipovala nové stále expozície múzea a publikovala niekol'ko článkov a štúdií o bratislavských stredovekých a barokových pamiatkach i umelcoch. ${ }^{7}$ Paralelne ale medzi rokmi 1924 - 1929 študovala dejiny umenia na bratislavskej univerzite v Žákavcovom seminári rozširujúc pritom svoje poznatky štúdiom vo Viedni. ${ }^{8}$ A v roku 1933 získala na Univerzite Komenského v Bratislave doktorský titul v odbore dejiny umenia - prehistorická archeológia. ${ }^{9}$ Nasledujúce roky jej života boli až

a doplnenou verziou. Pozri tiež KOLBIARZ CHMELINOVÁ, K.: University Art History in Slovakia after WWII and its Sovietization in the 1950s. In: Artium Questiones, 30, 2019, s. 161-190.

6 Bližšie pozri ŠIDLÍKOVÁ, Z.: Móda na Slovensku v medživojnovom obdobi (1918 - 1938). Bratislava 2011, s. 192-198.

7 ŠEFČÁKOVÁ, E.: Alžbeta Güntherová-Mayerová - život a dielo, s. 18-19 a FRANCOVÁ, Z.: Pôsobenie Alžbety Güntherovej-Mayerovej v Mestskom múzeu v Bratislave v rokoch 1930 - 1937 oba príspevky In: HERUCOVÁ (ed.) 2003, c. d. (v pozn. 1), s. 18-19, 82-98. K problematike pozri tiež ORIŠKOVÁ, M.: Naše staršie sestry: kustódky a kurátorky na Slovensku v prvej polovici 20. storočia. In: Artemis a Dr. Faust. Ženy v českéch a slovenskejych dèjinách umèní. Eds.: BÁRTLOVÁ, M. - PACHMANOVÁ, M. Praha 2008, s. 48-61.

8 Archív výtvarného umenia Slovenská národná galéria Bratislava (AVU SNG), Osobný fond Alžbety Güntherovej-Mayerovej (OF AGM), index Alžbety Mayerovej, sign. 10 A 11, 10 A 3. Index k fondu KOVALČÍKOVÁ, M.: Alžbeta Güntherová-Mayerová: súpis archivneho fondu. Bratislava SNG 1986. ŠEFČÁKOVÁ 2003, c. d. (v pozn. 3), s. 16, pozn. 11 uvádza 17. február 1925 ako dátum vydania indexu, ale výpis z prednášok dokazuje, že študovala už v roku 1924, resp. v akademickom roku 1924/25.

9 KOLBIARZ CHMELINOVÁ - BEŇOVÁ 2018, c. d. (v pozn. 5), s. 117. 
neuveritel'ne činorodé, spojené takmer so všetkými kl'účovými inštitúciami a oblast'ami umenovedného života na Slovensku. Odborná verejnost' sa ich v rôznych spracovaniach dotýka len sporadicky, s rešpektom a bázňou. Odrádza ju nepochybne rôznorodost' a zložitost' problematiky daná širokým profesijným záberom Güntherovej-Mayerovej spojená s komplikovaným štúdiom neúplnej, roztrúsenej i dobovo skreslenej materiálovej základne.

Pri pohlade na doterajší obraz Alžbety Güntherovej-Mayerovej zaráža očividná absencia bližšej znalosti jej pôsobenia na Univerzite Komenského. Mapa skromných publikovaných faktov o jej pedagogickej činnosti na tejto univerzite ukazuje vel'mi neistý terén, po ktorom sa treba vydat'. Chatrné údaje sa totiž len na málo miestach zhodujú, často sú zmätočné či úplne chýbajú. ${ }^{10}$ Dôvody tohto stavu dokumentácie a reflexie univerzitného pôsobenia Güntherovej-Mayerovej zrkadlia aj ambivalentný postoj vedenia univerzity po roku 1949 k jej kádrovo nevhodnej a potencionálne problematickej, avšak odborne, napriek všetkému, nevyhnutne potrebnej osobe.

\section{Lektorka muzeológie}

Prvou problematickou otázkou pedagogickej činnosti Alžbety Güntherovej-Mayerovej na Univerzite Komenského v Bratislave je: Kedy s ňou vlastne začala? V prvých prácach o nej sa opakujú konštatovania počiatkov lektorského pôsobenia na Univerzite Komenského v druhej polovici 30. rokov

${ }^{10}$ Zhoda nepanuje ani v rokoch jej pôsobenia na univerzite. Doteraz najspolahlivejšie súhrnné údaje In: ŠEFČÁKOVÁ 2003, c. d. (v pozn. 3), s. 24 uvádza roky 1940 - 1952 a 1955 - 1961. Inde rôzne zmienky podla povahy textov, porovnaj LUXOVÁ 1975 - 1976, c. d. (v pozn. 2) uvádza, že v druhej polovici 30. rokov 20. storočia pôsobila ako lektorka múzejníctva a od 1955 ako odborná asistentka Filozofickej fakulty Univerzity Komenského (FiF UK). KUBÍKOVÁ 1983, c. d. (v pozn. 2) píše, že medzi rokmi 1936-1942 bola lektorkou múzejníctva (FiF UK) a od roku 1955 nastupuje ako odborná asistentka. PETERAJOVÁ, L.: Pôsobenie Alžbety Güntherovej-Mayerovej na Vysokej škole výtvarných umení. In: HERUCOVÁ (ed.) 2003, c. d. (v pozn. 1), s. 99-101 $\mathrm{z}$ indexu K. Vaculíka dokladá jej pôsobenie na FiF UK od akademického roku 1942 - 1943 po 1946/1947 a potom od roku 1948 - 1949. Podla ŽATKULIAK, J.: Perzekúcie učitel’ov v rokoch 1948-1989. In: Zločiny komunizmu na Slovensku

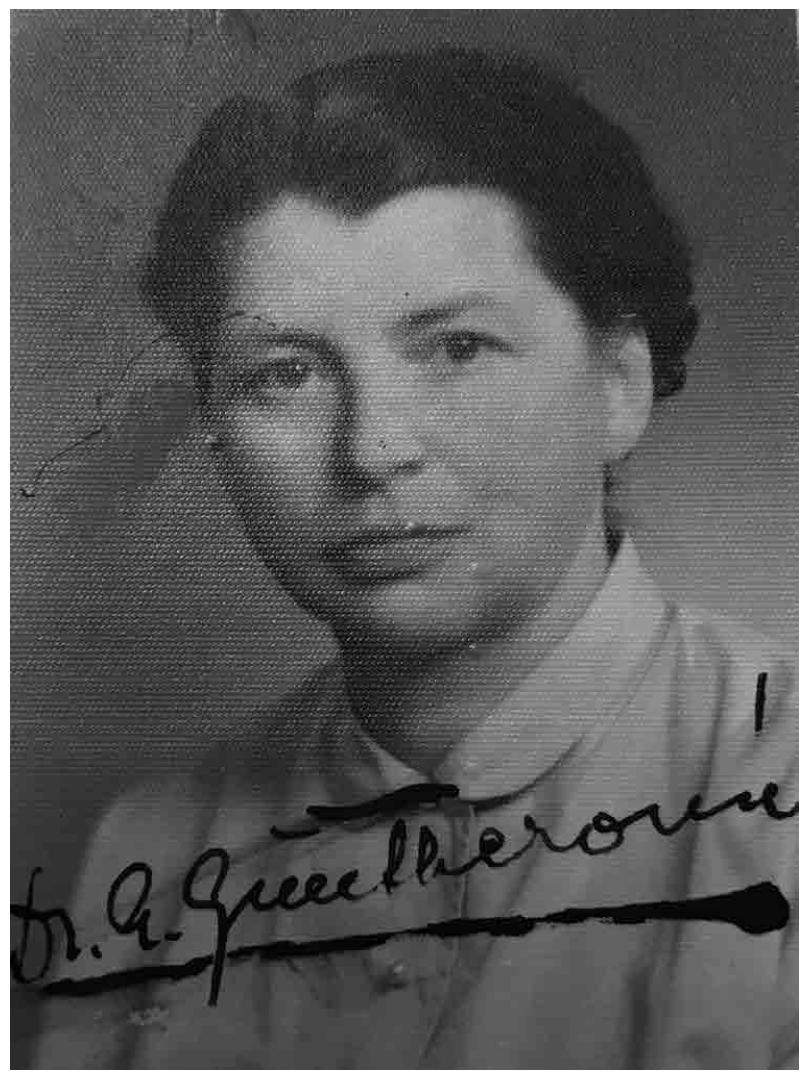

Obr. 1: Alžbeta Güntherová-Mayerová, jún 1954 Betliar. Foto: ALU SNG Bratislava.

20. storočia, resp. ako sama uviedla konkrétne od roku 1936. ${ }^{11} \mathrm{~V}$ neskoršej literatúre sa však vytrácajú, posúvajú sa až do 40 . rokov, prípadne sa uvádza už

1948 - 1989. Ed.: SMOLÍKOVÁ, G. Prešov, 2001, s. 672 bola po februári 1948 z Univerzity Komenského prepustená. BAKOŠ 2000, c. d. (v pozn. 4), s. 13 uvádza jej pôsobenie na FiF UK v akademických rokoch 1942 - 1944, následne krátky dočasný návrat v roku 1950 so skorým núteným odchodom a potom 1955 - 1961. CIULISOVÁ 2011, c. d. (v pozn. 4), s. 48 pozn. 20, s. 61 potvrdzuje návrat v roku 1955, zmienená je ale medzi externými prednášajúcimi. CHMELINOVÁ BEŇOVÁ (ed.) 2018, c. d. (v pozn. 5), s. 14, 64-67 zmienky o jej pôsobení v spomienkach a v neúplne zachovaných publikovaných zoznamoch prednášok v rokoch 1944/1945 - až 1949/1950, 1953, 1957/1958 a 1958/1959.

${ }^{11}$ Najskôr ho uvádza samotná Güntherová-Mayerová pri svojich spomienkach In: 100 rokov Mestskébo múzea 1968, c. d. (v pozn. 2), s. 305. LUXOVÁ 1975 - 1976, c. d. (v pozn. 2) zmieňuje $v$ tejto súvislosti všeobecne druhú polovicu 30. 
len jej trvalé pôsobenie v 50. rokoch 20. storočia. Naposledy sa túto otázku pokúsila na základe prameňov zodpovedat' Eva Šefčáková. V prínosnej štúdii z roku 2003 zmieňuje bez bližšej argumentácie, že spolu s výpomocou v Martine uplatňovala $\mathrm{v}$ roku 1936 skúsenosti z múzejnej praxe v lektorských prednáškach na Filozofickej fakulte dnešnej Univerzity Komenského, v tom čase Slovenskej univerzity v Bratislave. Následne stanovuje jej nástup do práce na bratislavskej univerzite do roku 1940 na základe zachovaného menovania na nehonorovanú lektorku tvrdiac, že odvtedy tu prednášala až do roku $1952 .{ }^{12}$ Zverejnené zoznamy prednášok a osôb pôsobiacich na univerzite medzi rokmi 1936 - 1940 vrátane, Alžbetu Güntherovú-Mayerovú ako prednášajúcu neuvádzajú. No je pravda, že kvôli tlači vznikali nielen $\mathrm{s}$ istým predstihom, ale ako sa ukázalo v niektorých prípadoch nie vždy úplne dôsledne odzrkadl'ovali skutočnost'. ${ }^{13}$ Doklady potvrdzujúce prednášky Güntherovej-Mayerovej na Slovenskej univerzite už v závere 30. rokov 20. storočia však ležia v archívoch. V Archíve výtvarného umenia Slovenskej národnej galérie sa okrem iného nachádza potvrdenie z Povereníctva školstva vied a umení z 23. októbra 1952, v ktorom sa píše, že Güntherová-Mayerová pôsobila na Slovenskej univerzite nepretržite od roku

rokov 20. storočia. KUBÍKOVÁ 1983, c. d. (v pozn. 2) uvádza bez bližšej argumentácie konkrétne roku 1936. Neskoršie porovnaj pozn. č. 9 .

12 ŠEFČÁKOVÁ 2003, c. d. (v pozn. 3), s. 21 a 24. K pôsobeniu v Martine, kde sa pokúšala aj trvalejšie zamestnat' sa zachoval aj jej pracovný denník. Pred tým jej lektorské pôsobenie od akademického roku 1936/37 na Univerzite Komenského, opät' bez uvedenia zdroja spomína v úvode publikácie napr. aj PETROVÁ-PLESKOTOVÁ 1995, c. d. (v pozn. 2), s. 7.

${ }^{13}$ Güntherová-Mayerová sa v týchto publikovaných zoznamoch zamestnancov a prednášok Filozofickej fakulty nenachádza. V rokoch 1934/35 - 1938/39 ju tu pri dejinách umenia, ako lektor stále vedený len Ján Hoffmann. Registratúrne stredisko FiF UK, Zoznamy prednášok FiF UK v Bratislave v rokoch 1934 - 1940. Rovnako Registratúrne stredisko FiF UK, Soznam osob a prednášok UK/SU 1934 - 1938, č. 16, $1934 / 35$, s. 34,$35 ; 1935 / 36$, s. 35 , $97,106,1936 / 37$, s. 37 , 46, 54, 99-100, 1937/38, s. 28, 37, 49, 54, 100, 112, 1938/39, s. $35,36,40,59,1939 / 40$, s. $27,35,45,88,1940-41$, s. $37-38$, 54, 105, 115-116. Ani v poslednom uvedenom roku sa pri vyučujúcich i lektoroch Güntherová-Mayerová nenachádza hoc už mala poverenie prednáškami, rovnako sa tu neuvádza
1936. ${ }^{14}$ Okrem toho je tu i rukopis, ktorý Šefčáková síce v súvislosti s týmito prednáškami neuvádza, no správne ho identifikovala ako text venovaný histórii dejín umenia na univerzite pre publikáciu Univerzita Komenského 1945 - 1955 vydanú v roku 1957. Text vznikol v čase ked' už Alžbeta Güntherová-Mayerová trvalo pôsobila na Filozofickej fakulte Komenského univerzity a $\mathrm{v}$ podstate viedla tamojšie dejiny umenia. Preto možno predpokladat', že ak by aj nebol napísaný priamo ňou, tak iste s jej vedomím niekým z vtedajšej nevel'kej subkatedry. V ňom sa uvádza, že A. Güntherová-Mayerová spolu s V. Menclom prednášala v umenovednom seminári už od roku 1937 pričom text jedným dychom naznačuje, že jej odchodom do Martina sa tieto prednášky stali iluzórnymi. ${ }^{15}$ V súvislosti s nimi je potrebné vziat' do úvahy, že rok 1936 bol v jej živote plný zmien - okrem sobáša sa JUDr. Erikom Güntherom bola z pracovného hl'adiska $\mathrm{v}$ Mestskom múzeu $\mathrm{z}$ neznámych príčin degradovaná na pozíciu kronikárky, zúčastnila sa súbehu na miesto v Martine, ale tiež mesiac zastupovala Alberta Kutala v Zemskom múzeu v Brne. (obr. 2) Jej odborné uplatnenie sa začalo čoraz viac presúvat' mimo bratislavského múzea. Okrem iného do spomenutého Martina a zrejme i na Filozofickú fakultu Univerzity Komenského. Alžbeta Günthe-

pedagogická fakulta, len právnická, lekárska a filozofická.

14 AVU SNG, OF AGM, Potvrdenie z Povereníctva školstva, vied a umení z 23.10.1952, sign. 10 I 538. Rovnako je to uvedené aj v jej životopise AVU SNG, OF AGM, Životopisy A. Güntherovej-Mayerovej, od 1952, 10 I 436. Doslovne je v strojom písanom a rukou spoznámkovanom dvojstranovom texte vo formáte A5 zaznamenané „, popri zamestnani v żmluvnom pomere: 1936 - 1955 prednásajúca na fil. fak. Komenskébo univerzity (múzejnictvo, dejiny umenia)"V d’alších dvoch záznamoch jej životopisných údajov od rôznych autorov v tejto zložke údaje varírujú s počiatkom lektorského pôsobenia v zimnom semestri napr. v roku 1938, v roku 1939. Okrem toho rok 1936 ako počiatok svojej výučby múzejníctva na Univerzite Komenského v Bratislave uvádza sama Alžbeta Güntherová-Mayerová vo svojich spomienkach na mestské múzeum In: 100 rokov Mestského múzea v Bratislave. c. d., (cit. v pozn. 2), s. 309.

${ }^{15}$ AVU SNG, OF AGM, sig. $10 \mathrm{~K}$ 610, s. 3. K pôsobeniu v Martine pozri: PEKÁRIKOVÁ, B.: Alžbeta Güntherová-Mayerová - jej činnost' v Slovenskom národnom múzeu v rokoch 1937 - 1942. In: Stretnutie so zivotom a dielom Alžbety Güntherovej-Mayerovej 2003, c. d. (v pozn. 1), s. 70-81. 


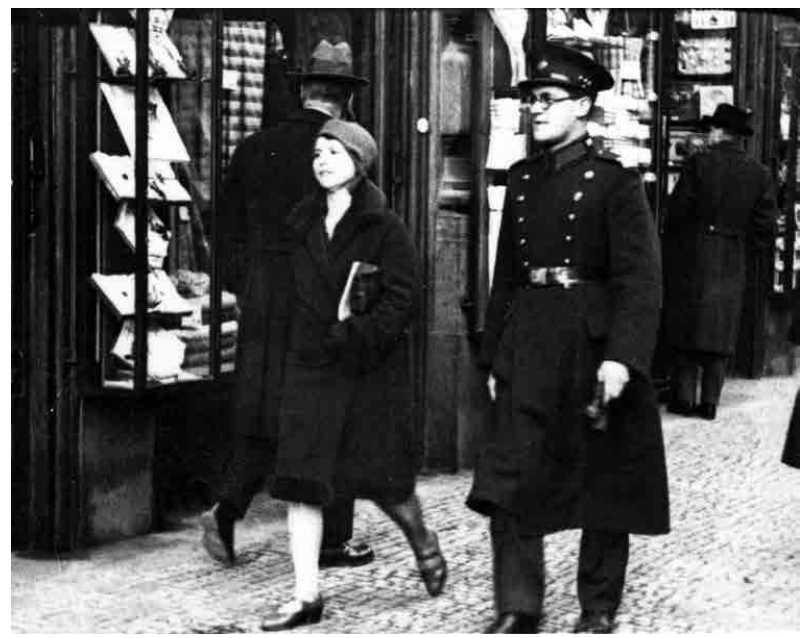

Obr. 2: Aľ̌beta Güntherová-Mayerová s manželom Erikom Güntherom, koniec 30. rokov 20. storočia. Foto: ALU SNG Bratislava.

rová-Mayerová medzitým preukázala svoj odborný rast nielen spoluautorstvom kapitoly Umenie v Československej vlastivede $\mathrm{z}$ roku 1934, ale publikovala i viaceré príspevky o gotickom a barokovom umení zvlášt' z prostredia Bratislavy a jej okolia. ${ }^{16}$ Túto ranú fázu jej odborného pôsobenia ovplyvneného aj jej predchodkyňou $\mathrm{v}$ bratislavskom Mestskom múzeu Gizelou Weydeovou-Leweke uzatvára v roku 1937 jej aktívna participácia vo výkonnom výbore

\footnotetext{
${ }^{16}$ Pozri KRESÁK, F. - ZÁVADOVÁ, K.: Bibliografia prác Alžbety Güntherovej-Mayerovej. In: ARS, 9-10, 1975-1976, c. $1-4$, s. 333 .
}

${ }^{17}$ VACULÍK 1974, c. d. (v pozn. 2), s. 356. CIULISOVÁ 2011, c. d. (v pozn. 4), s. 39-40. Staré umèni na Slovensku, Praha hrad - červen - srpen 1937, katalóg výstavy, Umělecká beseda Praha 1937; OROSOVÁ, M.: Návrat k výstave Staré umění na Slovensku v Prahe v roku 1937. In: Galéria - Ročenka Slovenskej Národnej Galérie v Bratislave, 2011, s. 71-87. K práci Weydeovej-Leweke a Güntherovej-Mayerovej ako kustódiek a kurátoriek pozri: ORIŠKKOVÁ 2008, c. d. (v pozn. 7).

${ }^{18}$ Bližšie k prof. Žákavcovi pozri CIULISOVÁ 2011, c. d. (v pozn. 4), s. 17-19.

${ }^{19}$ Registratúrne stredisko FiF UK Bratislava, Osobný spis AGM, sig. B II/1, 1954 spis č. 103.13.10.05 - bez bližšieho dátumu - Vec: Dr. Alžbeta Güntherová-Mayerová, návrh na udelenie miesta docenta na FF UK, príloha C - Prehl'ad praxe. nesmierne úspešnej a dnes už legendárnej výstavy Staré umenie na Slovensku v Prahe. ${ }^{17}$ Štýlovo-kritický prístup k materiálu, ktorý ju lákal, rozšírila v nasledujúcich rokoch o práce súpisového a muzeologického zamerania. Mimo to dopyt univerzity po prednáškach svojej bývalej absolventky $\mathrm{v}$ tom čase, mal zrejme i prozaickejší súvis so zdravotnou dovolenkou prof. Františka Źákavca ${ }^{18}$, ktorý preto v roku 1936 už neprednášal a čoskoro odišiel do dôchodku. Napokon k otázke počiatku tejto pedagogickej práce Güntherovej-Mayerovej sú tu ešte v mnohom rozporuplné doklady z jej osobnej zložky na Filozofickej fakulte Univerzity Komenského v Bratislave. V súvislosti s menovaním za štátneho docenta, je tu jej pôsobenie na univerzite spomínané viackrát. Najskôr je v dokladoch $\mathrm{k}$ návrhu na udelenie jej miesta docenta $\mathrm{v}$ roku 1954 zaznamená aj jej prax v podobe pedagogického pôsobenia na uvedenej univerzite a iných vysokých školách v Bratislave medzi rokmi 1939-1952. ${ }^{19}$ Podl'a zápisnice zasadnutia fakultnej návrhovej komisie z toho istého roku sama tvrdí, že bola lektorkou muzejníctva na Slovenskej univerzite v roku 1939/1940. ${ }^{20}$ Neskôr napríklad Zdeněk Wirth vo svojom posudku k jej habilitácii z roku 1956 uvádza počiatočný rok jej pôsobenia na univerzite ako 1936 a v rovnakom roku dekanát fakulty potvrdzuje nutnost' jej pôsobenia v Bratislave spolu s tvrdením, že bola lektorkou na fakulte od roku $1938 .{ }^{21}$

${ }^{20}$ Tamtiež, Zápisnica zo zasadnutia fakultnej návrhovej komisie pre prijatie Dr. Alžbety Güntherovej-Mayerovej za štátneho docenta pre odbor dejín umenia, 16. 5. 1954. Komisia na dekanstve fakulty bola v zložení - doc. J. Dekan - dekan FF, Prof. M. Bakoš, vedúci Katedry vied o umení, Dr. V. Wagner, prof. dejín umenia, Dr. Vladimír Matula, za Základnú organizáciu Komunistickej strany Slovenska a Ondrej Hajko, kádrový referent FF SU s poradným hlasom.

${ }^{21}$ Registratúrne stredisko FiF UK Bratislava, Osobný spis AGM, sig. B II/1, 5. 8. 1956 - Odpis posudku kvalifikačnej práce Alžbety Güntherovej-Mayerovej od Zdeňka Wirtha a 3. 9. 1956 Potvrdenie dekanátu o nutnosti pobytu Alžbety Güntherovej-Mayerovej v Bratislave. Pre úplnost' treba dodat', že v tomto osobnom spise sú ešte 2 doklady 29. 10. 1954 sa v ustanovení odborným asistentom FF UK od 1. 12. 1954 píše, že od roku 1945 bola externou prednášajúcou na FF a 2. 9.1955 je v tlačive návrhu na úpravu základného platu v kolónke doterajšie praxe uvedené aj „,externý prednášatel’ na FF UK od 1947“. Evidencia rôznych rokov jej pôsobenia na univerzite zrejme nie len zohl'adňovala rôzne pracovnoprávne vzt'ahy, ale bola ako vidno nedôsledná. 


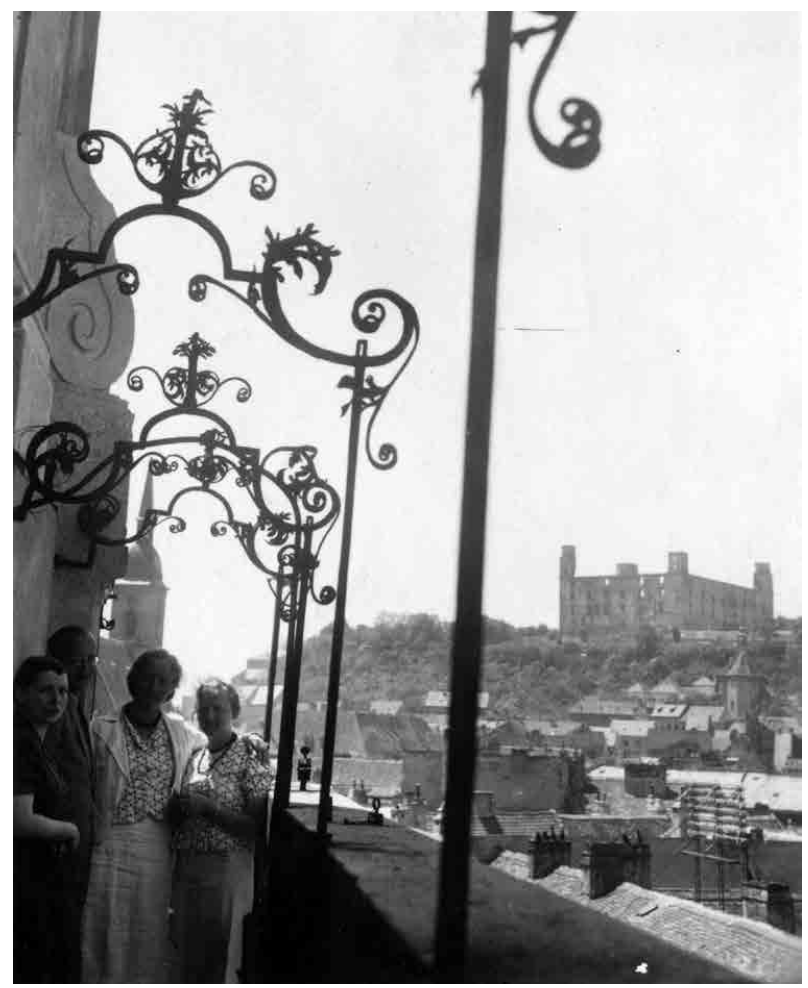

Obr. 3: Alžbeta Güntherová-Mayerová s kolegami na veži radnice v Bratislave, 1939. Foto: ALU SNG Bratislava.

Napriek nejednotnosti vyššie uvedených dokladov ohl'adne konkrétneho roku možno počiatky málo známeho pedagogického pôsobenia Güntherovej-Mayerovej na Univerzite Komenského v Bratislave zjavne spájat' už s druhou polovicou 30. rokov 20. storočia, s najnižšou eventuálnou hranicou v roku 1936. Každopádne však rozsah týchto jej vstupov do výučby samostatného Seminára dejín umenia, sformovaného a oficiálne, no skôr už len formálne vedeného ešte jej prof. F. Žákavcom, nebol vel'ký.

22 Slovník historiku umèní, výtvarných kritikü, teoretikù a publicisti. Ed.: SLAVÍČEK, L. Praha 2016, zv. I A-M. s. 241-242; zv. II. N-Ž̆, s. 1732-33.

${ }^{23}$ CHMELINOVÁ - BEŇOVÁ (ed.) 2018, c. d. (v pozn. 5), s. 64. V akademickom roku 1944/1945 dejiny umenia prednášala v priestoroch Archeologického seminára Filozofickej fakulty vtedajšej Slovenskej univerzity na Šafárikovom námestí č. 12 len Dr. Alžbeta Güntherová-Mayerová.
'Treba tiež konštatovat', že podl'a všetkého išlo len o externe a zdá sa dočasne poskytované lektorské prednášky z muzeológie, čomu mala zodpovedat' ich tematická náplň. O ich obsahu a charaktere nemáme bližšiu predstavu, ked’že sa k nim nedochovali žiadne známe podklady. Realizované boli popri jej pracovných povinnostiach v iných inštitúciách. (obr. 3) Mali súvis so situáciou okolo ukončenia prednášok a smrti prof. F. Žákavca v roku 1937, kedy začala univerzitná výučba dejín umenia trpiet' personálnou podvýživou a provizórnymi riešeniami. Odborné prednášky externe a dočasne suploval profesor, dekan a neskôr prodekan Masarykovej univerzity v Brne Eugen Dostál a formálne seminár viedol tunajší profesor prehistorickej archeológie Ján Eisner. ${ }^{22}$

\section{Externistka a výklady z dejín umenia}

Ďalšie otázniky sa spájú so zriedka a ked’ tak iba výberovo zmieňovanými univerzitnými prednáškami Güntherovej-Mayerovej zo 40. rokov 20. storočia strácajúcimi sa za množstvom jej vtedajšej múzejnej a pamiatkarskej práce. Dobové oficiálne zverejnené zoznamy prednášok ju v súvislosti so Seminárom dejín umenia uvádzajú len v dvoch akademických rokoch 1944/45 a 1949/50, ale ako to v skutočnosti bolo? ${ }^{23}$ Počiatkom 40. rokov ju neisté vojnové udalosti, podl'a jej životopiscov, donútili na čas opustit' Bratislavu. Spojené boli s Turcom i Oravou, kde v tom čase realizovala súpisové diela mapujúce tamojší pamiatkový fond. Na jar v roku 1941 končí pracovný pomer s magistrátom mesta a už ako skúsená múzejná pracovníčka a členka Muzeálnej slovenskej spoločnosti nastúpila do Slovenského múzea v Bratislave. ${ }^{24}$ (obr. 4) Zároveň z decembra 1940 máme zachované už zmienené menovanie Güntherovej-Mayerovej za lektorku múzejníctva, potvrdené prof. Jánom Stanislavom, vtedajším

${ }^{24}$ ŠEFČÁKOVÁ 2003, c. d. (v pozn. 3), s. 25.

${ }^{25}$ KOKLESOVÁ, B.: Seminár dejín umenia v rokoch 1939 1945. In: 95 rokov Filozofickej fakulty UK, Pobl'ad do dejin inštitúcie a jej akademickej obce. Ed. SLOBODNÍK, M. - GLOSSOVÁ, M. Bratislava 2017, s. 306-322.

${ }^{26}$ BAKOŠ 2000, c. d. (v pozn. 4), s. 11. 
dekanom Filozofickej fakulty premenovanej Slovenskej univerzity, pričom v tejto pozícii pôsobila na univerzite súvisle až do roku 1952. Počas vojny bola na Slovensku, na rozdiel od Čiech, zachovaná kontinuita univerzitnej výučby. Rovnako i štúdium dejín umenia tu ostalo nad'alej dostupné iba na Slovenskej univerzite $\mathrm{v}$ Bratislave, podliehajúcej však dobovému politicko-ideologickému diktátu nemeckej kultúrnej politiky. ${ }^{25}$ Fungovanie Seminára dejín umenia v 40. rokoch 20. storočia pritom odráža d'alšie provizórne riešenia. Po odchode E. Dostála v roku 1942 ho čisto formálne do roku 1948 viedol významný literárny vedec Andrej Mráz, ktorému krátko asistoval Aurel Zavarský (1946/47). ${ }^{26}$ No v prevažnej väčšine sledovaného obdobia predstavovali lektorské výklady Güntherovej-Mayerovej jediné tu dostupné umenovedné prednášky. $\mathrm{V}$ indexoch čítame, že išlo v priemere len o dva kurzy ročne zviazané s múzejnou a pamiatkárskou praxou majúce len jednohodinovú týždennú dotáciu, ako napríklad Konzervačné a inštalačné práce v múzeách a Zist'ovanie pravosti diel v akademickom roku 1942/194327, Sochárke techniky a ochrana pamiatok v roku 1944 či Základné pojmy zberatel'stva a múzejníctva a Vývoj štýlov vo výtvarnom umení v roku $1946 .{ }^{28}$ Tie prirodzene nemohli rozsahom saturovat' potreby cielenej vysokoškolskej výučby dejín umenia.

$\mathrm{Na}$ rozdiel od 30. rokov 20. storočia si predstavu o obsahu a charaktere týchto prednášok Güntherovej-Mayerovej už možno urobit' na základe rukopisu jednej z nich. V archíve Slovenskej národnej galérie sa totiž zachoval jej text výkladu o sochárstve a jeho technikách z roku 1945. ${ }^{29}$ (obr. 5) Ide o rukou, úhladným písmom husto zapísaných osem strán, predstavujúcich súvislý text s odkazmi na konkrétne diela, tvorcov, roky, termíny (v slovenskej a sčasti i nemeckej podobe) či iné údaje v zátvorkách, ktoré zjavne mali byt' počas prednášky vol'ne komentované. Vzhl’adom na vybrané príklady diel od Lyssipa po Augusta Rodina nie je vylúčené, že prednáška bola sprevádzaná premietanými diapozitívmi zo Žákav-

\footnotetext{
${ }^{27}$ Ibidem, s. 25, pozn. 41. V roku $1942 \mathrm{v}$ máji musela prejst' previerkou o nežidovskom pôvode. Doklad v podobe svedectiev o politickej spol'ahlivosti a osvedčení v AVU SNG, OF AGM, sign. 10 I 421, 10 I 432 a 433, z roku 1945, sign. $10 \mathrm{~K} 619$, z roku 1947 sign. 10 I 434.
}

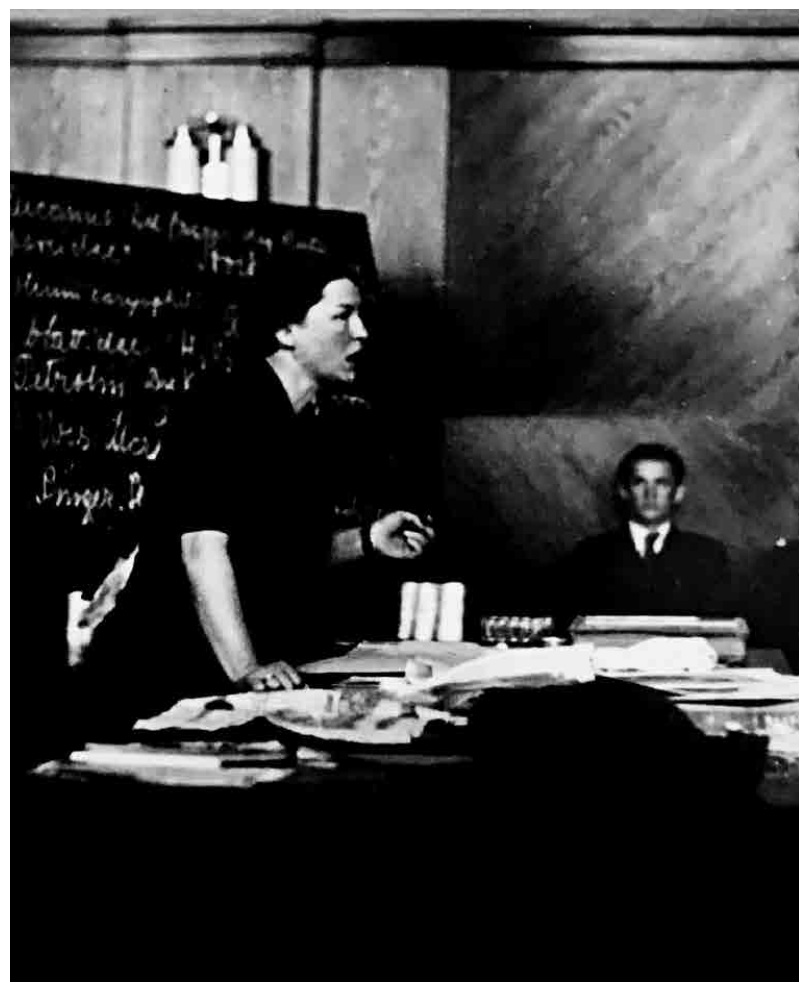

Obr. 4: Alžbeta Güntherová-Mayerová prednáša na Kurze Zväzu slovenských múzei v Martine, 1943. Foto: ALU SNG Bratislava.

com založenej výučbovej kolekcie seminára. Text s prehladnou štruktúrou je v prvej časti dokladom systematického prístupu s praktickým zameraním na základnú klasifikáciu sochárskeho výtvarného prejavu. Reflektujúc dobový, dnes sčasti prekonaný stav bádania, začína definovaním sochárstva - plastiky ako výtvarného druhu s poukazom na limity jeho vyjadrovacích možností videných v obmedzenej farebnosti a izolovanosti námetov od pôvodného prostredia. Následne približuje členenie sochárstva podl'a spôsobu zobrazenia, podl'a materiálu a techniky, funkcie a rozmeru. Nadväzuje objasnením prípravných fáz sochárskych realizácií, významu

${ }^{28}$ PETERAJOVÁ 2003, c. d. (v pozn. 8), s. 100. Okrajovo tiež PETERAJOVÁ, L.: Nepýtaj sa na svoj osud. Život a dielo Karola Vaculika. Bratislava 2005, s. 72.

${ }^{29}$ AVU SNG, OF AGM, Rukopis lektorskej prednášky o sochárstve, sign. 10 E 342. 


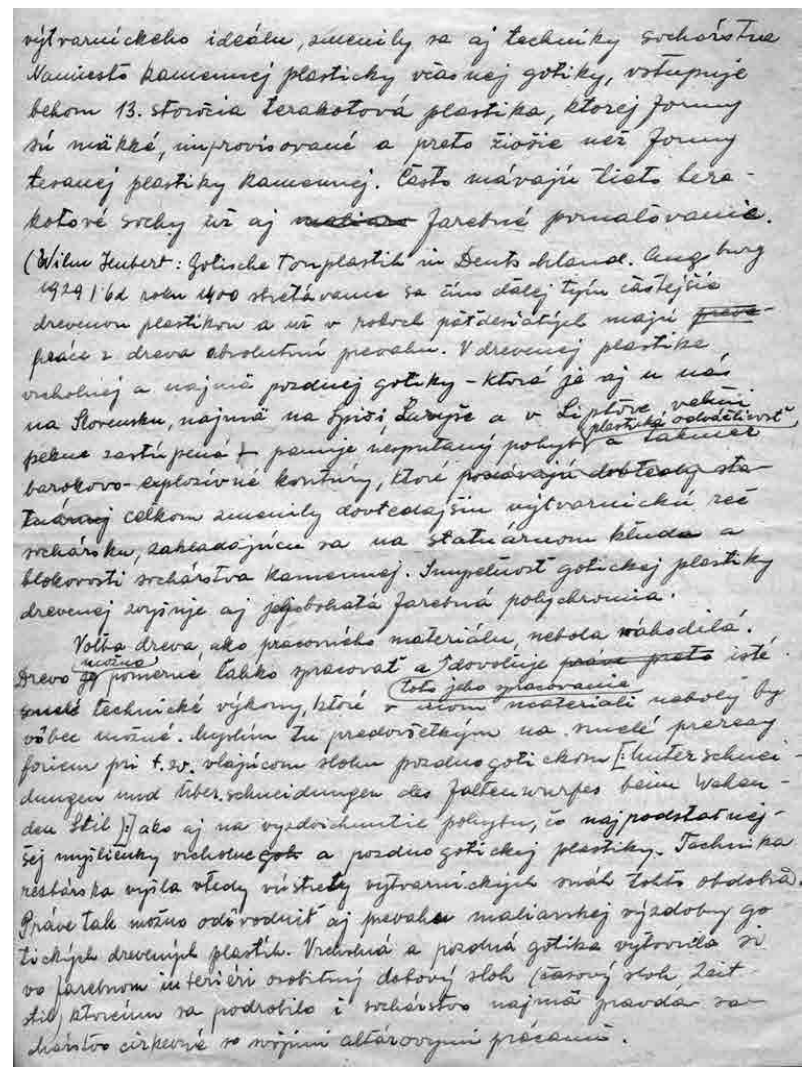

Obr. 5: Detail rukopisu lektorskej prednášky Alžbety Güntherovej-Mayerovej o sochárstve, 1945. Foto: ALU SNG Bratislava.

kresbových skíc, ako aj plastických bozzet. Druhá polovica prednášky je tvorená akousi neukončenou sondou do technologických dejín rezbárstva zameraných na obdobie gotiky. Táto preferencia vyplynula pravdepodobne $z$ charakteru pamiatkového fondu na našom území čakajúceho po vojne na spracovanie. Sústredený záujem oň už v tom čase viedol Güntherovú-Mayerovú k rozvinutiu idei umeleckohistorickej topografie s internacionalisticky chápaným uhorským kontextom a špecifickej teritoriálnej identity umenia na Slovensku, z čoho sa neskôr odvinuli aj základy pre neskorší súpis pamiatok. ${ }^{30}$

${ }^{30}$ BAKOŠ, J.: Situácia dejepisu umenia na Slovensku. Analekta VI. Bratislava, SNG, 1984, s. 68-96.

${ }^{31}$ OROSOVÁ, M.: Alžbeta Güntherová-Mayerová a Národná kultúrna komisia. In: HERUCOVÁ (ed.) 2003, c. d. (v pozn.

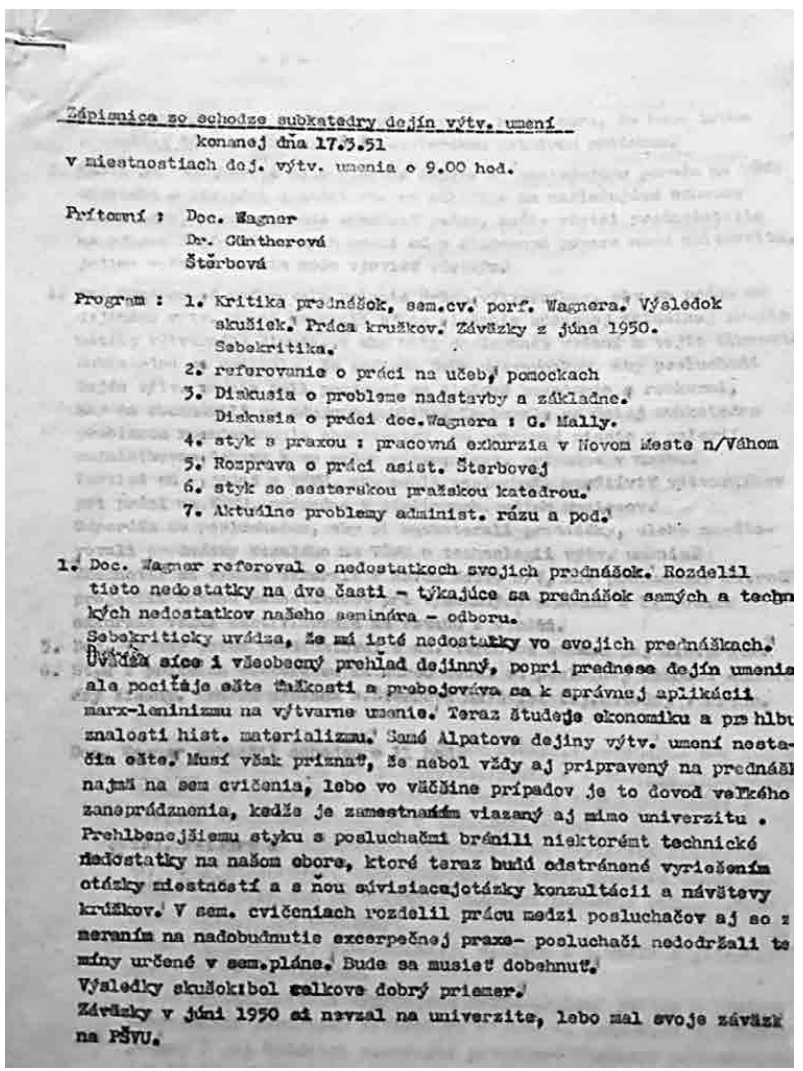

Obr. 6: Úvod zápisnice zasadnutia subkatedry dejín umenia Slovenskej university $v$ Bratislave, marec 1951. Foto: Archiv KDVU FiF UK Bratislava.

Koniec vojny bol v osobnom i pracovnom živote Alžbety Güntherovej-Mayerovej plný zmien. V roku 1945 sa jej narodil syn a od nasledujúceho roku jej početnú novú agendu prinieslo zamestnanie na Povereníctve školstva a národnej osvety v referáte ochrany pamiatok, kde spolu s Vladimírom Wagnerom riešila problematické reštitúcie, konfiškáty či vyhlasovanie a saturovanie kultúrnych pamiatok. ${ }^{31}$ Nemalú čast' jej vtedajšej práce predstavovala organizačná činnost' spojená so zakladaním rôznych ustanovizní. Mala svoj podiel na zrode Slovenskej národnej galérie, Vysokej školy výtvarných umení

1), s. 48-58. Ju spolu s Wagnerom, ako žiakov českých profesorov na Slovensku bez nových údajov spomína MLYNÁRIK, J.: Českí profesori na Slovensku. I. Českí profesori a ich slovenskí žiaci na Univerzite Komenského v rokoch 1919-1949. Praha 1994, s. 158-159. 
či pamiatkových orgánov. ${ }^{32}$ Zároveň Güntherová-Mayerová pokračovala aj vo vysokoškolskej pedagogickej činnosti a po vojne prednášala na Filozofickej, ale i novo založenej Pedagogickej fakulte Slovenskej univerzity (otvorená 6. 12. 1946). $\mathrm{V}$ júni roku 1946 sa dokonca stala honorovanou docentkou Slovenskej vysokej školy technickej pre odbor výtvarná estetika. ${ }^{33}$ Jej odborná rozhl'adenost' spolu s dobrou orientáciou v potrebných zákonoch a administratívnymi zručnost’ami získanými zvlášt' prácou na povereníctve smerovali neraz $\mathrm{k}$ návrhom koncepčných zmien, $v$ tomto prípade napr. mali podobu návrhu reformy školenia profesorov kreslenia. ${ }^{34} \mathrm{~V}$ publikačnej praxi reflektovala svoje skúsenosti z ochrany pamiatok a zároveň sa v súlade s povojnovými trendami začala venovat' aj otázkam súčasného umenia, zaujímajúc sa tak ako i predtým nie len o tzv. umenie vysoké, ale aj umelecké remeslo či l'udový výtvarný prejav. ${ }^{35}$ Spektrum jej odbornej pôsobnosti sa teda opät' rozrástlo reflektujúc aktuálne potreby umenovednej praxe na Slovensku. Namiesto úzkeho tematického zamerania smerovalo $\mathrm{k}$ encyklopedickej erudovanosti.

$\mathrm{V}$ rýchlom slede zmien $\mathrm{v}$ povojnovo sa konštituujúcom svete došlo u nás s prevratom $\mathrm{v}$ roku $1948 \mathrm{k}$ razantnej premene politických pomerov i ku zmenám v školskej správe. Neobišlo to prirodzene ani dejiny umenia, ktorým sa cielene rozrastala inštitucionálna základňa súčasne so zmenou chápania ich spoločenskej úlohy. ${ }^{36}$ Nasledovala aj markantná zmena odboru na univerzite $\mathrm{v}$ rovine personálnej, štrukturálnej a napokon i obsahovej. Cielom zmien bolo čo najlepšie napodobenie vysokoškolského systému Sovietskeho zväzu s jeho podriadením štátnemu aparátu. Komunistická strana, tak ako aj $\mathrm{v}$ iných krajinách sovietskeho vplyvu, získala kontrolu nad administratívou škôl, menovala rektorov,

${ }^{32}$ LUXOVÁ 1975-1976, c. d. (v pozn. 2), s. 330.

33 AVU SNG, OF AGM, Návrh na udelenie titulu honorovaného docenta, 15.6.1946, sign. 10 I 432 a Doklad o prijatí a realizovaní návrhu na udelenie titulu honorovaného docenta Slovenskej vysokej školy technickej Povereníctvom školstva, vied a umení, 3.10.1946, sign. 10 I 532. Dokument sa odvoláva na výnos z 12.9.1946. SEFČÁKOVÁ 2003, c. d. (v pozn. 3), s. $26-27$.

34 AVU SNG, OF AGM, Návrh na reformu školenia profesorov kreslenia a výtvarnej výchovy na Slovenskej vysokej škole

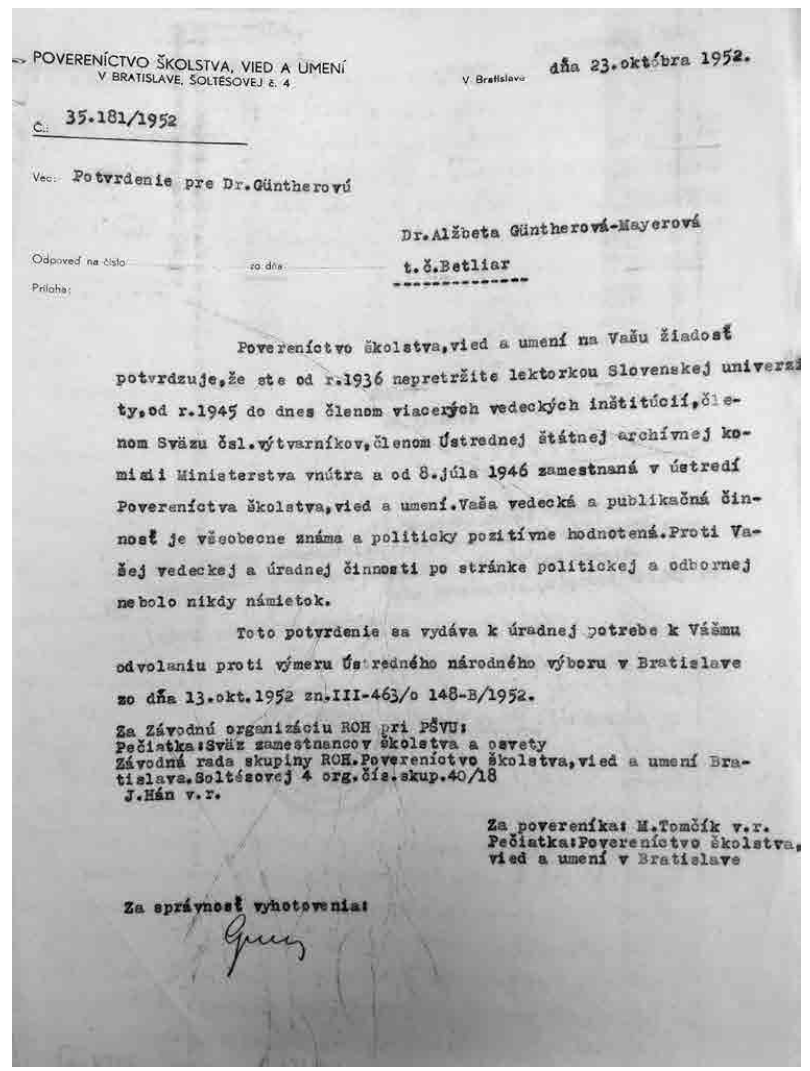

Obr. 7: Potvrdenie Poverenictva školstva, vied a umeni o pôsobeni Alžbety Güntherovej-Mayerovej, 1952. Foto: ALU SNG Bratislava.

zaviedla výučbu marxizmu-leninizmu a cielene napodobovala sovietsky model. Napriek existencii spoločného štátu bol proces sebasovietizácie vysokého školstva diferencovaný a napríklad dobovo príznačná deštrukčná sila politických previerok na Slovensku bola krátko po roku 1948 neporovnatel'ne menšia ako v Čechách. ${ }^{37} \mathrm{~V}$ Bratislave sa vedúcim seminára

technickej v Bratislave, 10 K 622. ŠEFČÁKOVÁ 2003, c. d. (v pozn. 3), s. 26-27.

${ }^{35}$ KRESÁK - ZÁVADOVÁ 1975 - 1976, c .d. (v pozn. 15). Ku kontextu pozri KUSÁ, A.: Prerušená pieseñ. Výtvarné umenie v časoch stalinskej kulturrnej praxe 1948 - 1956, Bratislava 2019.

${ }^{36}$ BAKOŠ 1984 , c. d. (v pozn. 29), s. 79-80.

${ }^{37}$ KOLBIARZ CHMELINOVÁ 2019, c. d. (v pozn. 5), s. 167-169. 
dejín umenia nakrátko stal Dostálov a Mukařovského odchovanec Jaroslav Dubnický, no s jeho odchodom na post dekana Filozofickej fakulty Slovenskej univerzity v roku 1950 skončila nadlho aj samostatnost' seminára predstavovaného $\mathrm{v}$ tom čase primárne V. Wagnerom, ešte Václavom Menclom a lektorkou Alžbetou Güntherovou-Mayerovou. Včlenený bol najskôr do odboru vied o umení a následne do rôznych umelo transodborovo koncipovaných katedier. ${ }^{38}$ Spoločensko-politické zmeny mali na Güntherovú-Mayerovú tragický dopad. V roku 1949 jej bol štátnou bezpečnost'ou pri výsluchu zabitý manžel. Vykonštruovaný bil'ag kolaborácie s USA sa na dlhé roky preniesol i na ňu. Stala sa terčom udaní vedúcich $\mathrm{v}$ roku $1952 \mathrm{k}$ nútenému odchodu $\mathrm{z}$ fakulty. ${ }^{39}$ Súčasne dostala príkaz na vysídlenie z Bratislavy $\mathrm{v}$ rámci akcie $\mathrm{B}$ namierenej pôvodne proti fašistom, následne proti buržoáznym a štátne nespol'ahlivým elementom. S malým synom, invalidným bratom a sesternicou sa musela prest'ahovat' do Betliara, kde bola poverená správou kaštiel’a i ned’alekého

${ }^{38}$ BAKOŠ 2000, c. d. (v pozn. 5), s. 12-13; CHMELINOVÁ BEŇOVÁ (ed.) 2018, c. d. (v pozn. 5), s. 65-66. Katedry sa začali organizovat' na konci akademického roku 1949/50 súčasne s prerokovaním zákona č. 58/1950 o vysokých školách. Katedry Slovenskej univerzity boli organizačne dobudované na začiatku akademického roku 1950/51.

39 AVU SNG, OF AGM, List Povereníctva školstva vied a umení o poverení správou kaštiel’a v Betliari z 12. 10. 1952. Pozri tiě̌ ŠEFČÁKOVÁ 2003, c. d. (v pozn. 3), s. 28-29.

${ }^{40}$ Bližšie pozri BARCZI, J: Alžbeta Güntherová-Mayerová roky vyhnanstva 1952 - 1955. In: Monument revue, 2, 2013, č. 1, s. 28-32. Archív Slovenského národného múzea - Múzeum Betliar, Pracovný denník Alžbety Güntherovej-Mayerovej, 1952-1955.

${ }^{41}$ AVU SNG, OF AGM, List Povereníctva školstva z 12. októbra 1952, sign. 10 I 538. ŠEFČÁKOVÁ 2003, c. d. (v pozn. 3), s. 29. Pôsobenie Güntherovej-Mayerovej na východe Slovenska neznamenalo však stratu jej živých väzieb na Bratislavu a sa neviazalo len na Betliar či Gemer, ale spájalo sa i s pamiatkami napríklad z Košíc, Bardejova či Levoče. Svoje miesto našlo v jej rastúcej publikačnej činnosti, pozri: KRESÁK - ZÁVADOVÁ 1975-1976, c .d. (v pozn. 15). GLASOVÁ, A.: Doplnok k bibliografii prác Alžbety Güntherovej-Mayerovej. In: Ars, 17, 1983, č. 1, s. 85-86. KRESÁK, F. - ZÁVADOVÁ, K. - GLASOVÁ, A.: Bibliografia prác Alžbety Güntherovej-Mayerovej. In: PETROVÁ-PLESKOTOVÁ 1995, c. d. (v pozn. 2), s. 211-223. hradu Krásna Hôrka. ${ }^{40}$ (obr. 8) Jej vzdelanie, vzácne schopnosti a kompetentnost' sa v istom zmysle stali jej záchranou a to nie len pri Novomestského prezieravej zmene jej vyst'ahovania, určeného pôvodne na Jednotné rol’nícke družstvo v obci Husinec, na Betliarsky kaštiel' so zbierkami Andrássyovcov, kde ich mohla a mala uplatnit'. ${ }^{41}$

Medzitým sa na konci akademického roku 1949/50 na Slovenskej univerzite začali organizovat' katedry, nahrádzajúc predchádzajúce Semináre (obr. 11). Dialo sa to súčasne s prerokovaním zákona č. 58/1950 o vysokých školách, ktorý bol vyústením ,socialistických reforiem“. ${ }^{42}$ Nasledujúce dva roky boli zahájením radikálnej sebasovietizácie vedecko-výskumnej základne realizovanej trojicou procesov: implementáciou uvedeného zákona; oddel'ovaním vedeckej činnosti od pedagogickej a politicko-výchovnej určenej vysokým školám a napokon politickými čistkami. ${ }^{43}$ Katedry Slovenskej univerzity boli organizačne dobudované na začiatku akademického roku 1950/51. Zároveň bola v roku 1951

${ }^{42}$ https://www.slov-lex.sk/pravne-predpisy/SK/ZZ/1950 /58/19660501 (15.5.2018). Katedrám je venovaný \ 15.

Katedry podl'a neho zriad'uje minister školstva, vied a umení, pričom môže ku katedre jednej fakulty priradit' učitel'ov inej fakulty tej istej vysokej školy, poprípade inej vysokej školy. Vedie ich profesor katedry, ktorého ustanovuje a odvoláva minister školstva, vied a umení na návrh Štátneho výboru. Študijné a skúšobné plány pre jednotlivé študijné odbory ustanoví po dohode so zúčastnenými členmi vlády minister školstva, vied a umení. Minister školstva, vied a umení vydáva aj študijné a skúšobné poriadky a študijné osnovy. $\mathrm{Na}$ to boli naviazané rôzne vykonávacie predpisy, o. i. Nariadenia o organizačných zmenách na Vysokých školách z roku 1951, 1952 aj 1953. K situácii v Čechách Déjiny Univerzity Karlovy IV. (1918-1990). Eds.: HAVRÁNEK, J. - POUSTA, Z. Praha 1998; ŠTEMBERKOVÁ, M.: Univerzita Karlova. Historický prehled. Praha 2011. PETRÁN, J.: Filozofové dèlají revoluci. Filozofická fakulta Univerzity Karlovy běbem komunistického experimentu (1948-1968-1989). Praha 2015, najmä s. 138-142, 168-263. Aktuálne BARTLOVÁ, M.: Déjiny českèch dèjin umèní 1945 - 1969. Praha 2020, s. 90-100, 455.

${ }^{43}$ KOLBIARZ CHMELINOVÁ 2019, c. d. (v pozn. 5), s. 168-169. K procesom sovietizácie vo vysokom školstve u nás porovnaj GABZDILOVÁ, S.: Ako sme študovali v totalite. Vysokoškolské vzdelávanie na Slovensku pod ideologickým dik.tátom Komunistickej strany Ceskoslovenska 1948 - 1953, Prešov 2018. HUDEK, A.: Sovietizácia pracovísk historickej vedy na Univerzite Komenského v 50. rokoch, In: SLOBODNÍK GLOSSOVÁ (ed.) 2017, c. d. (v pozn 25), s. 338-354. 
aj v slovenskom dejepise umenia stalinská ideológia povýšená na normatívny kánon. ${ }^{44}$

\section{Skorý návrat}

Po Güntherovej-Mayerovej vyst'ahovaní odišiel v roku 1953 z bratislavskej univerzity z ideologických dôvodov, tentokrát už definitívne, aj V. Mencl, pôsobiaci tu po vojne tiež ako externista. Avšak netrvalo dlho a ukázala sa nutnost' opätovného zaradenia Güntherovej-Mayerovej, Žákavcovej žiačky a poslucháčky Hansa Tietzeho, do výučby dejín umenia na univerzite. Podl'a spomienok Karola Kahouna sa túto personálnu úpravu našt’astie podarilo prof. Mikulášovi Bakošovi „vymodlit“" na vedení univerzity. ${ }^{45}$ (obr. 8 a 9) V septembri 1953 tak z Filozofickej fakulty Slovenskej univerzity v Bratislave obdržala poverenie realizovat' prednášky a cvičenia v akademickom roku 1953 - 1954 označené ako Umenie byzantské a východoeurópske do 18. storočia a Umelecký priemysel. ${ }^{46}$ Ide o rovnaké prednášky, akými bola poverená suplovaním už v roku $1951 .{ }^{47}$ V odpovedi naň Güntherová-Mayerová podáva návrh, aby z dôvodu vzdialenosti jej pracoviska v Betliari a zdĺhavého dochádzania mohla realizovat' výučbu $\mathrm{v}$ blokoch $\mathrm{s}$ mesačnou periodicitou. ${ }^{48}$ Napokon ale prichádzala po dvoch týždňoch. Každoročne publikované zoznamy prednášok fakulty práve z rokov 1953 - 1957 v archívoch Univerzity Komenského chýbajú, no obraz o nich si môžeme urobit' z poverenia, študijných plánov či spomienok absolventov alebo ich indexov. Alžbeta Güntherová-Mayerová spočiatku tieto už nie muzeograficky, ale primárne umenovedne orientované prednášky patriace do jadra výučby odboru realizovala zdíhavo

${ }^{44}$ CIULISOVÁ, I.: Lesk a bieda slovenskej kunsthistórie II (Slovenský dejepis umenia 1948 - 1968), In: CIULISOVÁ 2011, c. d. (v pozn. 4), s. 61.

${ }^{45}$ CHMELINOVÁ - BEŇOVÁ (ed.) 2018, c. d. (v pozn. 5), s. $14-15$.

${ }^{46}$ AVU SNG, OF AGM, Poverenie od Filozofickej fakulty Slovenskej univerzity konat' v školskom roku 1953 - 1954 prednášky, sign. 10 A 36.

47 Porovnaj Ibidem, Poverenie od Filozofickej fakulty Slovenskej univerzity konat' v školskom roku 1951 - 1952 prednášky

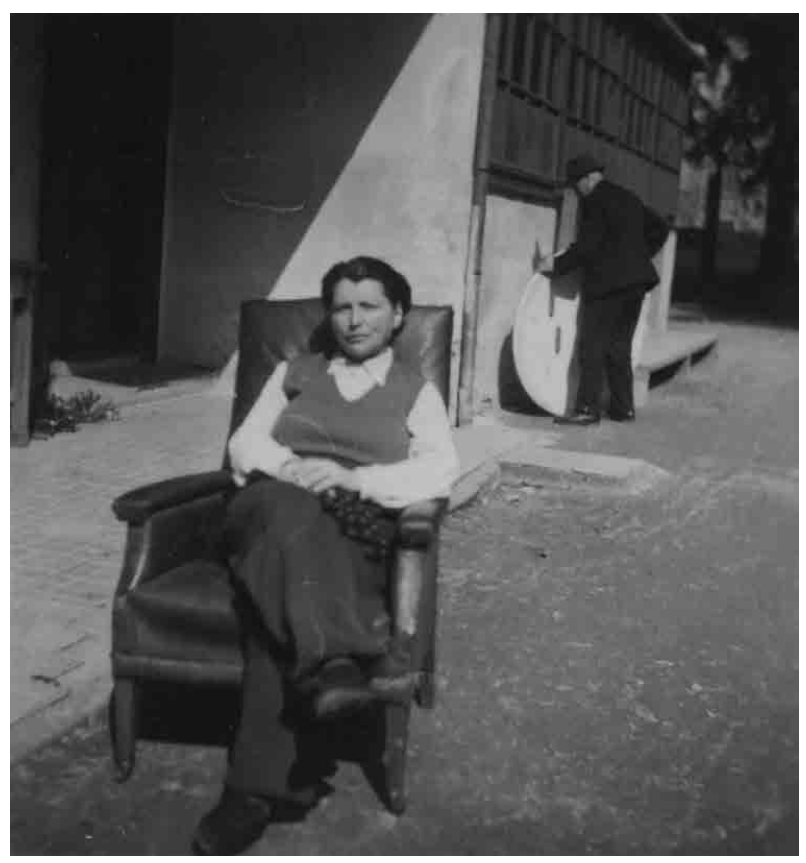

Obr. 8: Alžbeta Güntherová-Mayerová v Betliari, jar 1953. Foto: ALU SNG Bratislava.

dochádzajúc z Betliara. Jej príznačne zodpovedný prístup $\mathrm{k}$ nim i k študentom dokladá napr. list $\mathrm{K}$. Kahounovi z júna 1954, ktorý je d'alším z doteraz neznámych dokladov odhal'ujúcich realitu dobového vysokoškolského pôsobenia. ${ }^{49}$ (obr. 10) Stručný, no obsažný list bol sprievodným textom k zaslanej prvej časti jej neoficiálnych skrípt o umeleckom priemysle pre študentov, pričom Güntherová-Mayerová zároveň zist'uje či d'alší jej podklad pre štúdium predmetu o byzantskom umení bol už „odklepaný“ a teda

z 10.6.1951, sign. 10 I 527. Jedna 2 hodinová prednáška bola realizovaná v zimnom a druhá $\mathrm{k}$ umeleckému priemyslu bola realizovaná v letnom semestri.

${ }^{48}$ Ibidem, Odpoved' dekanstvu Filozofickej fakulty Slovenskej univerzity na poverenie prednáškami z 28. 9. 1953, sig. 10 A 74 .

49 Ibidem, Teoretické štúdie a poznámky k umeleckému priemyslu 1960, sign.10 C 129, zložka Poznámky k jednotlivým druhom umeleckého remesla 43/3, List K. Kahounovi z 9.6.1954. List je súčast'ou rukopisných poznámok o umeleckom remesle venovaných cínu. 


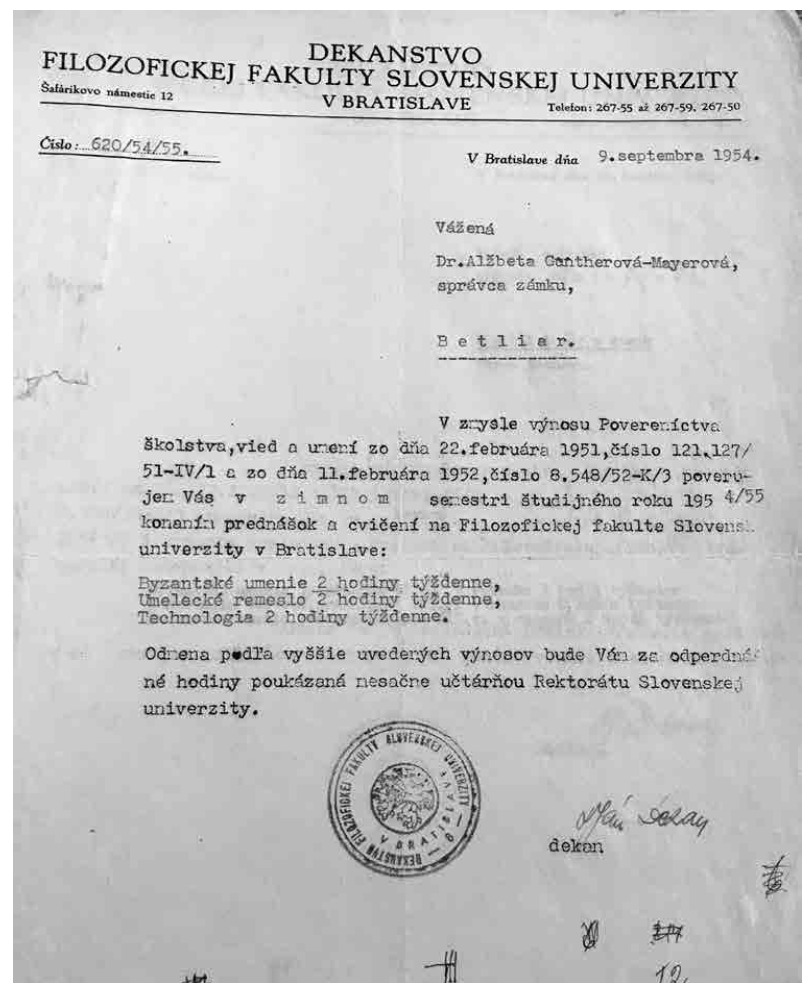

Obr. 9: Poverenie Aľ̌bety Güntherovej-Mayerovejprednáškami na Filozofickej fakulte Slovenskej university, 1954. Foto: ALU SNG Bratislava.

rozmnožený na použitie pre študentov. ${ }^{50}$ (obr. 15) Z textu je tiež zrejmé, že nie univerzita, ale Betliaru nadriadený Krajský národný výbor v Košiciach bol $\mathrm{v}$ tom čase jej hlavným zamestnávatel'om. ${ }^{51} \mathrm{~S}$ prednáškami, ktoré $\mathrm{v}$ liste spomína, sa $\mathrm{z}$ jej $\mathrm{v}$ archíve zachovaných rôznorodých prednáškových podkladov dajú spojit' minimálne dve časti. Jednak je to

${ }^{50}$ AVU SNG, OF AGM, Teoretické štúdie a poznámky k umeleckému priemyslu 1960, sign.10 C 129, v tom zložka označená ako Poznámky ku štúdiu umeleckého priemyslu, 43/3. Materiál napriek označeniu na obale rokom 1960 obsahuje okrem uvedenej i viaceré zložky a nedatované texty k týmto prednáškam o umeleckom priemysle evidentne $\mathrm{z}$ rôznych rokov, čast' zrejme ešte pre Univerzitu Komenského a čast' už určených pre Vysokú školu výtvarných umení. Nachádza sa tu aj dvojmo odpis podrobného sylabu k Prednáškam o umeleckom priemysle rozvrhnutý do 7 okruhov, podla ktorého si možno urobit' predstavu o celkovej štruktúre a obsahu kurzu. Sylabus nie je datovaný, no na druhom z nich je rukou komentár k literatúre z roku 1958, podl’a čoho možno súdit', že

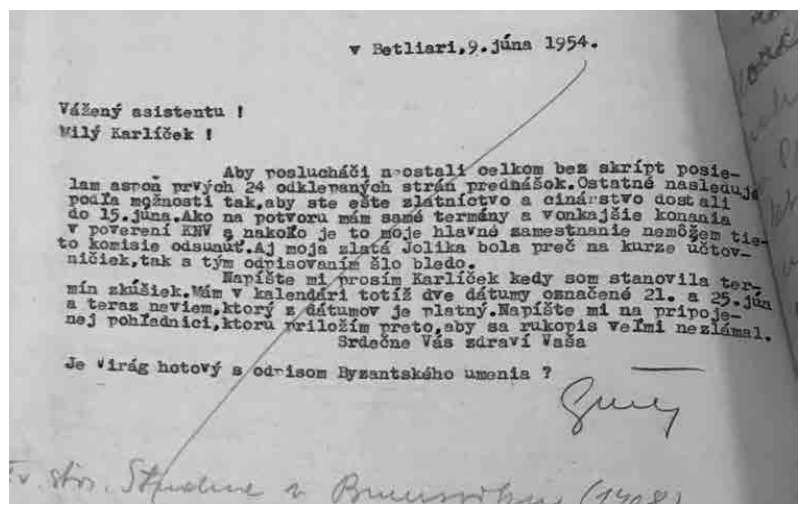

Obr. 10: Kópia listu K. Kahounovi od Aläbety Güntherovej-Mayerovej na rukopise jej prednášok, jún 1954 Foto: ALU SNG Bratislava

rukopis o cíne, ktorého je list súčast'ou, respektíve i celá $\mathrm{k}$ nemu prislúchajúca zložka s označením Poznámky ku štúdiu umeleckého priemyslu so samostatným materiálom napríklad ku zlatníctvu či kovanému železu. A potom k tomu patrí i „odklepaný““ úvod písaný strojom na tenkom rozmnožovacom papieri. $V$ ňom začína definíciou pojmu umelecký priemysel s následným objasnením jeho praktického využitia a nomenklatúry. Rovnako ako u vyššie zmienenej prednášky o sochárstve aj tie o umeleckom priemysle následne delí a skúma podl’a materiálu, ku ktorému viaže rozbory techník (niekedy i s odkazom na vhodné ošetrenie poškodení) a funkcie. Nasleduje subordinovaná chronológia vývoja a prvky znalectva, ako napríklad rozlišovanie majstrovských, kontrolných, miestnych a overovacích značiek u kovových realizácii. Güntherovej-Mayerovej prehl'adne systematizované prednáškové texty prezrádzajú pri

vznikol neskôr, do značnej miery však zohl'adňujúc štruktúru už pred tým vedeného kurzu. Potvrdzuje to aj zmenená dikcia textu a doplnenie obsahu o sledovanie vývoja vo feudálnej, kapitalistickej a socialistickej spoločnosti a zdôraznenie väzby medzi spoločnost'ou jej kultúrou a umením a teda aj s umeleckým priemyslom chápaným ako výraz doby. Prirodzene tieto zmeny reflektovali iste aj odlišný, verejnejší charakter textu.

${ }^{51}$ BARCZI 2013, c. d. (v pozn. 18), s. 32. V Betliari organizovala letné praxe pre študentov dejín umenia, pred tým $\mathrm{v}$ rokoch 1951-53 viedol V. Wagner praxe a exkurzie v Liptove, Turci a na Považí. 


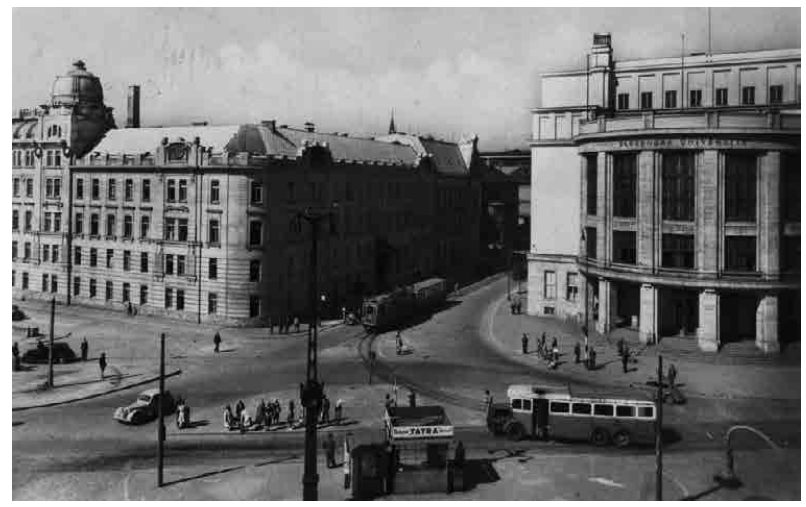

Obr. 11: Budory Filozofickej fakulty Univerzity Komenského v Bratislave (vlavo budova Povereníctva vnútra, vpravo budova v tom čase Slovenskej Univerzity), začiatok. 50. rokov 20. storočia. Foto: Archiv KDV U FiF UK.

bližšom pohl'ade úzku väzbu na materiál i autorkino vo Viedni koreniace štúdium. Poukazujú tiež na uplatnenie skúseností z jej skoršieho pedagogického pôsobenia v pozícii lektorky muzeológie. Zároveň možno konštatovat', že napriek všeobecnej dobovej požiadavke tieto výklady neobsahujú marxistickú interpretáciu dejín umenia. ${ }^{52}$ Vyhnút' sa jej umožňovala Güntherovej-Mayerovej práve orientácia na akceptované praktické funkcie disciplíny, ku ktorej ju naviac oprávňovala muzeografická a zároveň pamiatkarsko-ochranárska prax prehlbovaná aktuálnym pôsobením v Betliari. ${ }^{53}$

\section{Interná zamestnankyňa a vedenie odboru dejín umenia}

Už v nasledujúcom akademickom roku, súčasne s kodifikáciou študijných predpisov po nových systémových zmenách vo vysokom školstve ${ }^{54}$, markantne vzrástol rozsah i významu jej pôsobenia vo výučbe dejín umenia na Univerzite Komenského. $\mathrm{Na}$ rozdiel od jej menej obsažného poverenia

${ }^{52} \mathrm{~K}$ dobovým úlohám dejepisu umenia na Slovensku pozri BAKOŠ 1984, c. d. (v pozn. 29), s. 79-87.

${ }^{53}$ Napriek ,vyhnanstvu“ do Betliara mala Güntherová-Mayerová v umenovednom prostredí Slovenska nezastupitel'né postavenie, poukazuje naň okrem iného v oblasti pamiatkovej ochrany aj jej participácia na diskusiách okolo započatej rekonštrukcie Bratislavského hradu, pokračujúca v druhej polovici 50. rokov

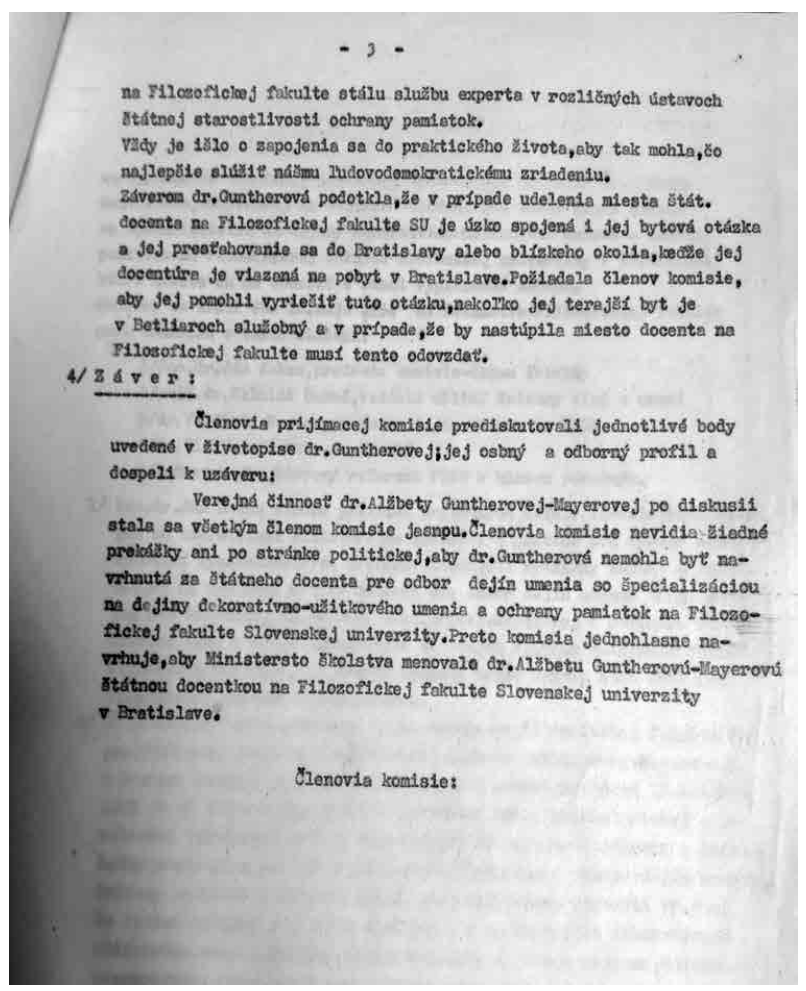

Obr. 12: Detail záveru zápisnice na miesto docenta na Filozofickej fakulte Slovenskej university, 1954. Foto: ALU SNG Bratislava.

(obr. 9) to dokumentuje študijný plán z rovnakého roku 1954 záväzný pre nové 5-ročné štúdium dejín umenia od akademického roku 1954/55. V porovnaní s tunajším predošlým pôsobením jej ich teraz z vyznačených predmetov a prednášajúcich pripadlo najviac. Boli to tri povinné prednášky - Svetové umenie 17. a 18. storočia, České a slovenské umenie 17. a 18. storočia a Umelecký priemysel, každá celkovo po šest'desiat hodín, pri šestnást' týždňovom semestri, čiže dva semestre po dve hodiny týždenne na každú. $K$ tomu ešte viedla dva volitel'né kurzy -

20. storočia. Archív Katedry dejín výtvarného umenia (KDVU) FiF UK Bratislava, Vyjadrenie k využitiu Bratislavského hradu - doklad o konferencii z 15. 8. a list z 26. 8. 1958. V tom čase už bola aj členskou expertnej komisie Slovenského pamiatkového úradu. ŠEFČÁKOVÁ 2003, c. d. (v pozn. 3), s. 31.

${ }^{54} \mathrm{Ku}$ zmenám aj s d’alšou literatúrou pozri KOLBIARZ CHMELINOVÁ 2019, c. d. (v pozn. 5). 
Muzeológia a Pamiatková ochrana. Na jeseň 1954, bola s úćinnost'ou od 1. decembra toho roku naviac ustanovená odbornou asistentkou fakulty. Nové, od predchádzajúcich tematicky odlišné, prednášky jej iste umožnili rozvíjat' nielen inšpirácie $z$ dejín umenia ako ich nazerala klasická fáza Viedenskej školy dejín umenia, ale aj už zmienený špecifický topografický prístup. ${ }^{55}$ A odovzdávat' ich spolu s vedomím podmienenosti materiálového výskumu a jeho teoretickej reflexie. Ako ukazuje archívny materiál i spomienky absolventov $^{56}$, boli jej prednášky svedomito pripravené v rukopise, následné prepísané na stroji či týmto spôsobom rozmnožené tak, aby boli dostupné študentom. Obrazový sprievodný materiál bol v tom čase komplikovane dostupný a zrejme používaný v obmedzenej miere. Vzhl'adom na aspoň čiastočnú vybavenost' subkatedry dejín umenia staršími diapozitívmi i premietacou technikou, možno však predpokladat' ich zapojenie do výučby. Absolventi spomínajú Güntherovú-Mayerovú ako pragmatického pedagóga vedúceho študentov k úzkemu kontaktu teórie a praxe využívajúc pritom potenciál priameho kontaktu s pamiatkami Bratislavy, ako i časté exkurzie do rôznych ateliérov, zbierkových inštitúcii či praxe $\mathrm{v}$ Betliari. Dejiny umenia podl'a nich prednášala $\mathrm{v}$ širokom spektre druhov a $\mathrm{v}$ ich kultúrnohistorickom kontexte akcentujúc význam interpersonálnych vzt'ahov pre vznik umeleckých diel ako aj teritoriálne špecifiká. Do výkladov zanietene integrovala vlastné skúsenosti o umeleckých technikách, praktickej ochrane pamiatok, znalectve a zberatel'stve či inštalačnej praxi.

${ }^{55}$ BAKOŠ 1984, c. d. (v pozn. 29), s. 68-69; BAKOŠ 2000, c. d. (v pozn. 4), s. 62.

${ }^{56}$ ZÁVADOVÁ, K.: Spomienky na Alžbetu Alžbeta Güntherovú-Mayerovú. In: HERUCOVÁ 2003 (ed.), c. d. (v pozn. 1), s. 42-47. K spomienkam K. Kahouna, D. Kahounovej a M. Pötzl-Malíkovej, E. Torana, K. Kubíčkovej pozri CHMELINOVÁ - BEÑOVÁ (ed.) 2018, c. d. (v pozn. 5), s. 14-15, 19-21, 26-28.

57 ŠEFČÁKOVÁ 2003, c. d. (v pozn. 3), s. 30. Dekan žiadal v máji 1954 jej posudok od prof. PhDr. Emanuela Pocheho, riaditel'a Uměleckoprůmyslového muzea v Prahe, ktorý poslal jednoznačne kladné hodnotenie.

${ }^{58}$ Registratúrne stredisko FiF UK, Osobný spis AGM, sig. B II/1, 1954 spis č. 103.13.10.05, Vec: Dr. AGM, návrh na
V rovnakom roku 1954 je doložená snaha Filozofickej fakulty Univerzity Komenského poskytnút' Güntherovej-Mayerovej zodpovedajúcu pozíciu docentky. ${ }^{57}$ Napriek tomu, že všetky jej posudky boli kladné a aj rozhodnutie fakultnej komisie na konkurze k tomuto miestu bolo jednohlasné konštatujúc, že nie sú žiadne prekážky ani po stránke politickej, návrh napokon nebol realizovaný. ${ }^{58}$ (obr. 12) Oficiálny dôvod známy nie je. Indície napovedajú, že za tým boli bohužial' skôr intrigy v inštitúcii a l'udská zášt' než pretrvávajúci tieň jej kádrovej nevhodnosti. To čo sa nepodarilo na pôde Komenského univerzity v rovnakom roku úspešne zrealizovala Slovenská vysoká škola technická, ktorá i tam prednášajúcu Alžbetu Güntherovú-Mayerovú vymenovala za štátnu docentku. ${ }^{59}$ Uvedený nárast záujmu i ocenenie jej práce navodzuje dojem pozitívnej zmeny v jej živote, no platilo to len v obmedzenej miere. V ostrom kontraste s uvedeným pracovným docenením je najskôr nútené komplikované dochádzanie z nekomfortného ubytovania bez vody v Betliari a následné jej nedôstojné ubytovanie v jednej izbe prerobenej z kúpel'ne na internáte v Horskom parku, kde až do roku 1963 bývala spolu so synom a po večeroch poskytovala konzultácie svojim študentom. ${ }^{60}$ Potvrdzuje to, že bil'ag kádrovo nevhodnej osoby s jeho negatívnymi dôsledkami jej napriek všetkému ostal.

Príznačný pre danú dobu i samotnú situáciu Alžbety Güntherovej-Mayerovej (nielen) na univerzite je dlho neznámy dokument zachovaný v jej osobnom archívnom fonde $\mathrm{v}$ SNG označovaný ako nedatované zhodnotenie vlastných prednášok z de-

udelenie miesta docenta na FF UK. Zložka okrem neúplnej publikačnej činnosti, prehladu praxe, posudkov obsahuje aj Zápisnicu zo zasadnutia fakultnej návrhovej komisie pre prijatie za štátneho docenta pre odbor dejín umenia. Posudzovatel'mi boli E. Poche a Jozef Vočnousy z odb. památkové péče Minnisterstva kultúry. Pohovor sa konal 16. 5. 1954 na dekanstve pred komisiou v zložení - doc. J. Dekan - dekan FF, Prof. M. Bakoš, vedúci Katedry vied o umení, Dr. V. Wagner, prof. dejín umenia, Dr. Vladimír Matula, za ZO KSS, Ondrej Hajko, kádrový referent FF SU s poradným hlasom. Druhým uchádzačom na toto miesto bol Jaromír Hlavsa.

59 ŠEFČÁKOVÁ 2003, c. d. (v pozn. 3), s. 31.

${ }^{60}$ ZÁVADOVÁ 2003, c. d. ( v pozn. 52), s. 43. ŠEFČÁKOVÁ 2003 , c. d. (v pozn. 3), s. 31. 
jín umenia. ${ }^{61}$ Ide o vyžadovaný, dobovo špecifický mocensko-kontrolný nástroj tzv. sebakritiky, ktorá mohla byt' len formalitou, ale rovnako mohla mat' fatálne dôsledky. Vzhl’adom na jej obsah dotýkajúci sa prednášok, ktorými bola Slovenskou univerzitou poverená v roku 1953 a zmienku o minuloročnej sebakritike ho možno datovat' do roku 1954 prípadne 1955. Necelé tri strany koncentrovaného vecného textu s jasnou štruktúrou sú nielen dokladom obdivuhodnej schopnosti Güntherovej-Mayerovej s nadhl'adom štylizovat' potencionálne nebezpečnú výpoved', ale aj možnost'ou objavovat' zákutia jej vnímania umenia a zároveň i dobového pedagogického pôsobenia na univerzite. Autorka začína pochvalou študentov odboru, následne v obsiahlom priblížení zamerania svojich prednášok o byzantskom umení cielene edukuje čitatel'a o politickej role tohto oficiálneho umenia. Odhal'uje tiež, že popri kultúrno-historickom kontexte jadra problematiky venovala zvláštnu pozornost' aj balkánskym štátom a interpretácii pravoslávneho umenia. Stručne konštatuje objektívny nedostatok obrazového materiálu, čo sa pokúsila aspoň čiastočne vyriešit' pripravením skrípt a zostavením kompletnej dostupnej bibliografie $\mathrm{k}$ téme pre študentov. Uvádza, že s prednáškami osobne nie je spokojná, považujúc ich len „za prvý súhrn bez náležitej komentácie“, pričom z ospravedlnenia vyplýva, že v tom čase prednášková činnost’ nebola jej hlavným zamestnaním a mohla ju pripravovat' len po nociach. Pokračuje samotnou autokritikou, podl'a ktorej je v „dôsledku objektivistickej výchovy málo priebojnác", citovým potenciálom umenia strhávaná

${ }^{61}$ AVU SNG, OF AGM, Zhodnotenie vlastných prednášok, sign. 10 E 322. Publikovaný prepis bez datovania a komentára: GÜNTHEROVÁ MAYEROVÁ, A.: Zhodnotenie vlastných prednášok z dejín umenia (rukopis, nedatovaný). In: Monument revue, 2, 2013, č. 1, s. 34. Datované a komentované KOLBIARZ CHMELINOVÁ 2019, c. d. (v pozn. 5).

${ }^{62}$ Použitie termín je v súlade s jeho dobovým využitím pozri Archív KDVU FiF UK Bratislava, Plán práce odboru dejín umenia na šk. rok 1958/59, s. 2. ....,zasadnutie odboru/quasi subkatedry/“. Tiež listy rektorátu Vysokej školy výtvarných umení v Bratislave o zastupovaní doc. Volavku z januára a februára 1958 adresované Subkatedre dejín umenia FiF UK. Proces emancipácie odboru potvrdzuje z dokladov tohto archívu aj Žiadost' o študijnú exkurziu dejín umenia z 18. 3. 1958 adresová dekanátu FiF UK, ktorú zaslali ako Katedra dejín umenia, hoc predstavovali len jednu súčast' vel'kej Katedry vied k emocionalite a umeleckým školením do istej miery $\mathrm{k}$ zálube vo formalizme. Diplomaticky pritom vytvára priestor na nápravu svojho „snád““ pasívneho postoja napr. naznačenou potrebou propagovania umenia. Posledný odsek je „peniazom dane"s volaním po novej forme agitačno-populárneho umenia dneška so šikovným vystríhaním pred jednostranným hodnotením zložitého fenoménu akým umenie je.

$\mathrm{V}$ dvoch rokoch obnoveného pôsobenia sa Güntherovej-Mayerovej na Slovenskej univerzite, premenovanej opät' na Univerzitu Komenského, podarilo osvedčit'. Len niekol'ko mesiacov pred nečakaným úmrtí V. Wagnera v marci roku 1955, sa konečne stala kmeňovým interným zamestnancom univerzity. Začína tým jej posledné, no najvýznamnejšie obdobie pôsobenia na Komenského univerzite, kedy oficiálne z postu odbornej asistentky, najbližších 6 rokov v skutočnosti prevzala Wagnerove povinnosti a viedla subkatedru ${ }^{62}$ (oficiálne odbor) dejín umenia, tvoriacu v tom čase súčast' vel'kej Katedry vied o umení vedenej prof. M. Bakošom. ${ }^{63}$ Vnímat' to treba $\mathrm{v}$ širšom kontexte výrazných zmien, ktorých bolo v tom čase vo vzt'ahu k univerzitným dejinám umenia viacero. Okrem iného v novembri 1954 v zápisnici celej Katedry vied o umení ćítame, že bol prof. M. Bakošom predložený návrh na jej rozčlenenie. Podl'a neho mali v roku 1955/56 z nej vzniknút' 3 samostatné katedry. ${ }^{64}$ Jednou z nich mala byt' samostatná Katedra dejín výtvarného umenia vedená prof. V. Wagnerom. Podrobnejší návrh mal byt' prílohou zápisnice, bohužial' dnes chýbajúcou a neznámou. Každopádne dnes už vieme,

o umení! Obdobná pozícia ženy, akú tu Güntherová-Mayerová zastávala bola v českom univerzitnom prostredí tej doby nemyslitel’ná. BARTLOVÁ 2020, c. d. (v pozn. č. 42), s. 74-84, 455.

${ }^{63}$ CHMELINOVÁ - BEŇOVÁ (ed.) 2018, c. d. (v pozn. 5), s. 66-67. Bližšie pozri tiež KOLBIARZ CHMELINOVÁ 2019, c. d. (v pozn. 5). Je na mieste pripomenút', že M. Bakoš patril predtým od roku 1937 k zakladajúcim členom dôležitého Spolku pre vedeckú syntézu, kde v tom čase pôsobil aj J. Dubnický. BAKOŠ, V.: Filozofia na pôde vedeckej syntézy (k 70. výročiu založenia) In: Filozofia, 62, 2007, č. 10, s. 853-869.

${ }^{64}$ Registratúrne stredisko Filozofická Fakulta Univerzity Komenského v Bratislave, Fond A II/1, A5 Zápisnice zo zasadnutí Katedry vied o umení 1951-1959, Zápisnica z 20. a 27. novembra 1954. KOLBIARZ CHMELINOVÁ 2019, c. d. (v pozn. 5), s. 175-176. 
že tento pokus nebol úspešný, napriek tomu idea osamostatnenia sa odboru vo forme katedry v nasledujúcich rokoch neutíchla. Okrem toho sa zrejme v súvislosti s vyššie uvedeným zámerom v rozmedzí rokov 1954/55 výrazne zmenila, rozrástla a na čas stabilizovala personálna skladba subkatedry dejín výtvarného umenia. Okrem Jírího Kostu, externej straníckej posily z Prahy od roku 1951 a opät' povolanej Güntherovej-Mayerovej, išlo najmä o markantný nástup novej generácie. Predstavovali ju okrem mladej Eleny Dubnickej budúce významné osobnosti našich dejín umenia, najskôr Radislav Matuštík s Tomášom Štrausom, primárne prijatí na estetiku avšak s výučbou aj dejín umenia, a po Wagnerovom odchode v roku 1955 Karol Kahoun. ${ }^{65}$ Z predchádzajúceho personálneho zabezpečenia odboru, ktoré v roku 1950 tvoril V. Wagner, V. Mencl, A. Güntherová-Mayerová a J. Dubnický ostala teda sama. Toto jeho nové posilňovanie od polovice 50 . rokov umožnili tiež dva faktory. V roku 1953 sa smrt'ou Josifa Vissarionoviča Stalina a Klementa Gottwalda končia roky tzv. l'avého sektárstva a nastáva obrat aj vo vede. Sovietsky experti v Československu na rozdiel od roku 1950 nabádali teraz k umiernenosti voči „buržoáznym odborníkom“ a kritizovali anti-intelektualizmus Komunistickej strany Československa. ${ }^{66}$ Namiesto šikanovania mala nastúpit' ich výchova $\mathrm{k}$ marxistickému svetonáhl'adu. Naviac stranícka rezolúcia z roku 1953 obmedzila právomoci svojich základných organizácii na vysokých školách náležiace opät' dekanom a rektorom. Okrem toho kl'účové štrukturálne a obsahové zmeny smerujúce vo vysokoškolskej výučbe $\mathrm{k}$ výchove novej inteligencie boli už zavedené a bolo sa teda možné načas viac sústredit' na skutočné problémy odborov.

$\mathrm{K}$ tomuto času sa, v porovnaní s predchádzajúcimi rokmi, zachoval $\mathrm{v}$ archíve katedry i $\mathrm{v}$ iných fondoch početnejší materiál umožňujúci vytvorenie

${ }^{65}$ BAKOŠ 2000, c. d. (v pozn. č. 4), s. 13; CHMELINOVÁ - BEŇOVÁ (ed.) 2018, c. d. (v pozn. 5), s. 12-14, 98-99. KOLBIARZ CHMELINOVÁ 2019, c. d. (v pozn. 5), s. 176, repr. 6. PETERAJOVÁ 2005, c. d. (v pozn. 28), s. 127-128. Externe vtedy prednášali tiež Tilkovský, Váross a krátko aj Vaculík. Tilkovský z Prahy mal dochádzat' a prednášal ešte aj v roku 1958/59 s úväzkom 4 hod. na semestre -2 kurzy - Metódy slohového rozboru a Národné umenie ludových demokracii. No v novembri 1958 bol ako externista potvrdený len Kostka. Porovnaj Archív KDVU FiF UK Bratislava, si jasnejšieho obrazu o charaktere a rozsahu tunajšieho pôsobenia Güntherovej-Mayerovej. Prirodzene oficiálnou metódou výučby bola $\mathrm{v}$ tom čase marxistická umenoveda, avšak v konkrétnej výučbe sprostredkovávala Güntherová-Mayerová tunajším študentom idei viedenskej školy dejín umenia najmä v jej Tietzeovskej verzii. ${ }^{67}$ Ako dokazujú zoznamy prednášok mala na svojich pleciach výučbu značnej čast' jadra odboru. Napríklad v akademickom roku 1957/58 učila Umenie byzantské a východných Slovanov, Stredoveké maliarstvo európske a v Cesko-slovenskej republike, d'alej svetové, ale aj české a slovenské umenie 17. a 18. storočia, Umelecký priemysel (obr. 15), Rakúske umenie a Slovensko a Seminár z dejín umenia. $\mathrm{V}$ tom čase boli priestory prislúchajúce dejinám umenia na univerzite ešte $\mathrm{v}$ budove na Safárikovom námestí 12. Už samotnou autorkou systematicky usporiadaný materiál z archívu katedry a Slovenskej národnej galérie dokumentuje nielen jej zodpovedný prístup k riešeným úlohám, ale najmä jej jasnú predstavu o potrebách a smerovaní odboru i jeho výučby. Okrem zápisníc zo zasadaní katedry obsahuje ňou pripravené oficiálne dokumenty písané s diplomatickým šarmom ohl'adne plánov práce, hodnotení skúšok a praxí, prípravy exkurzii, odporúčaní študentov i kolegov na výskum či do zamestnania, požiadaviek na získanie mikrofilmov, kníh alebo možností zahraničnej spolupráce atd'.

$\mathrm{V}$ čase zavedenia novej vyhlášky o vysokom školstve 46/1956 Zz, pripravila okrem podkladov ku svojej habilitácii (obr. 13) v júni toho roku po dohode s Kabinetom výtvarných umení Slovenskej akadémie vied návrh na zriadenie Ústavu dejín umenia pri Filozofickej fakulte Univerzity Komenského v Bratislave. Jeho úlohou malo byt' vedenie prieskumu, výskumu, heuristických a dokumentačných prác v oblasti dejín umenia na Slovensku podl'a plánu koordinovaného nie len so Slovenskou akadémiou vied,

Plán prednášok na školský tok 1958/59 so zdôvodnením označený na prepracovanie a jeho prepracovaná verzia z 23. 5. 1958, Potvrdenie externistov 27. 11. 1958. Tak ako aj predtým na prednášky externistov dohliadala Güntherová-Mayerová.

${ }^{66}$ HUDEK 2017, c. d. (v pozn. 41), s. 349. GABZDILOVÁ 2018, c. d. (v pozn. 41), s. 39.

${ }^{67}$ Ibidem. 
ale i Pamiatkovým úradom. Ústav mal byt' pričlenený k odboru dejín umenia na Univerzite Komenského. Zdôvodňuje sa to nedostatkom odborných kádrov na Slovenskej akadémii vied a tlakom na realizácie úloh súpisového, korpusového i slovníkového charakteru, do ktorého by okrem zamestnancov Univerzity Komenského mohli byt' úspešne integrovaní aj najlepší študenti odboru. Dokument, s hoc nerealizovaným zámerom, dokladá posilnenie pozície a nárast významu odboru dejín umenia za pôsobenia Alžbety Güntherovej-Mayerovej na Filozofickej fakulte Univerzity Komenského. Napriek trvajúcemu oficiálnemu začleneniu odboru do Katedry vied o umení, potvrdzuje uvedenú pozíciu tiež sebareflexia odboru a jeho úspešné presadzovanie sa s označením subkatedra či dokonca katedra. Napríklad v marci 1958 v žiadosti o študijnú exkurziu dekanátu posielajú z dejín umenia oficiálny list už ako Katedra dejín umenia. ${ }^{68}$ Mohlo to mat' prezieravý súvis s pohybmi okolo pripravovanej novej siete vysokých škôl a s normovaním vysokoškolskej práce, ktoré Katedra vied o umení prerokovávala na svojom zasadnutí v decembri 1958 a napokon aj s neskoršou reorganizáciou umenovedných smerov v roku 1960 v rámci potrieb dovíšenia kultúrnej revolúcie. ${ }^{69}$

$\mathrm{V}$ pracovnom pláne odboru na akademický rok 1958/59 spracovanom s ostatnými členmi ňou vedenej subkatedry popri členstvách, publikačnej a konkrétnej výskumnej činnosti členov katedry sa spomína najmä dôraz na potrebu prehíbenia kontaktu s praxou, prirodzene zároveň s povinnou politicko-výchovnou prácou. Pre tento účel zdôrazňuje materiál nutnost' viackrát ročne organizovaných exkurzii a žiada riešit' otázky praktického umožnenia kurzu fotografovania. ${ }^{70}$ Napokon za zmienku tiež stojí, že tento plán obsahuje aj jasné odlíšenie dvoch tu zastúpených vetiev odboru - historickej a esteticko-kritickej. Pre subkatedru/odbor dejín

\footnotetext{
${ }^{68}$ Archív KDVU FiF UK Bratislava, List z 18. marca 1958 dekanátu FiF UK. V tom čase Spomeňme tiež, že v letnom semestri akademického roku 1957/1958 Alžbeta Güntherová-Mayerová zastupovala aj doc. Vojtecha Volavku na Vysokej škole výtvarných umení. Archív KDVU FiF UK Bratislava, list rektorátu VŠVU adresovaný Subkatedre dejín umenia FiF UK zo 4. februára 1958.

${ }^{69}$ Archív KDVU FiF UK Bratislava, Zápisnica zo zasadnutia Katedry vied o umení 13. 12. 1958.
}

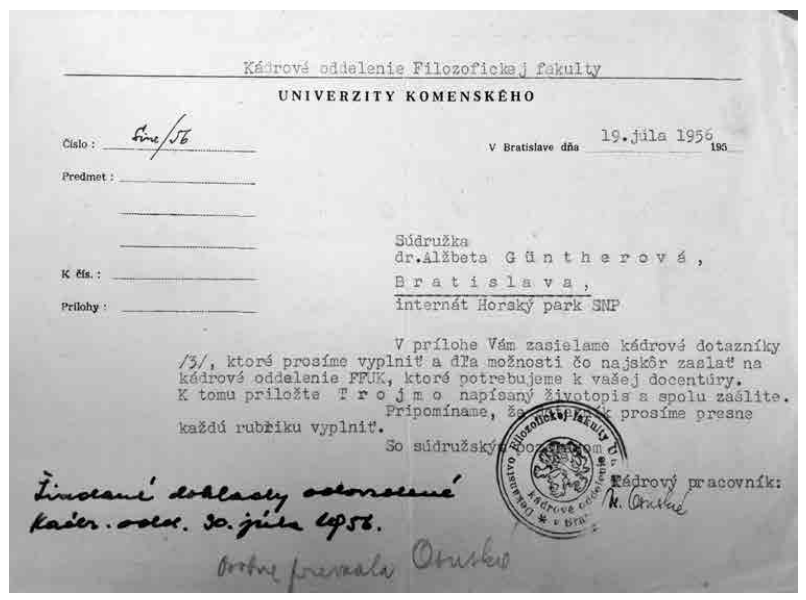

Obr. 13: Žiadost'o kádrové dotazníky k docentúre Alžbety Güntherovej-Mayerovej, júl 1956. Foto: RS FiF UK Bratislava.

umenia Güntherová-Mayerová v roku 1958 žiadala od vedenia fakulty (s. Janigošová) okrem iného: 4-5 skrín pre knižnicu, ktorú z priestorových dôvodov potrebujú čiastočne umiestnit' na chodbu k výt'ahu budovy na Šafarikovom námestí, kde vtedy sídlili. Ďalej kritizuje absenciu fotografickej komory a poukazuje aj na potrebu malých demonštračných zbierok, podobných ako majú archeológovia. Malo íst' o - umelecké remeslo, obrazy a sochy, ktoré by dostali z múzeí a galérii zdarma ako depozit.

Vo vzt'ahu k charakteru vysokoškolskej pedagogickej práce Güntherovej Mayerovej tiež vypovedá materiál z jej osobného archívneho fondu. Ten totiž obsahuje aj komplexne dokumentácie štátnych skúšok so zaznamenaním otázok i jednotlivých posudkov rôznych záverečných prác a ich obhajob budúcich známych osobností najmä z rokov 1956, 1957 a 1958. Materiál je dokladom jej i katedrového nezmazatel'ného podielu na významnej generácii historikov umenia formujúcich zvlášt' tretiu štvrtinu 20 . storočia. ${ }^{71} \mathrm{Z}$ jej

${ }^{70} \mathrm{~V}$ tom roku počítali pre exkurzie s Južnými Čechami, Prahou a plánovali i Drážd’any. Archív KDVU, Plán prác odboru dejiny umenia na šk. rok 1958/59, bez datovania a podpisu a Agenda k exkurziám 1958-1959.

71 AVU SNG, OF AGM. Záverečné skúšky absolventov dejín umenia 1956-1960, sig. 10 E 344, Tamtiež, návrh skúšobných otázok pre záverečné skúšky z dejín umenia 1956-1957, sign. 10 E 343, Tamtiež, Oponentské posudky, sign. 10 E 206, 10 E 233. 


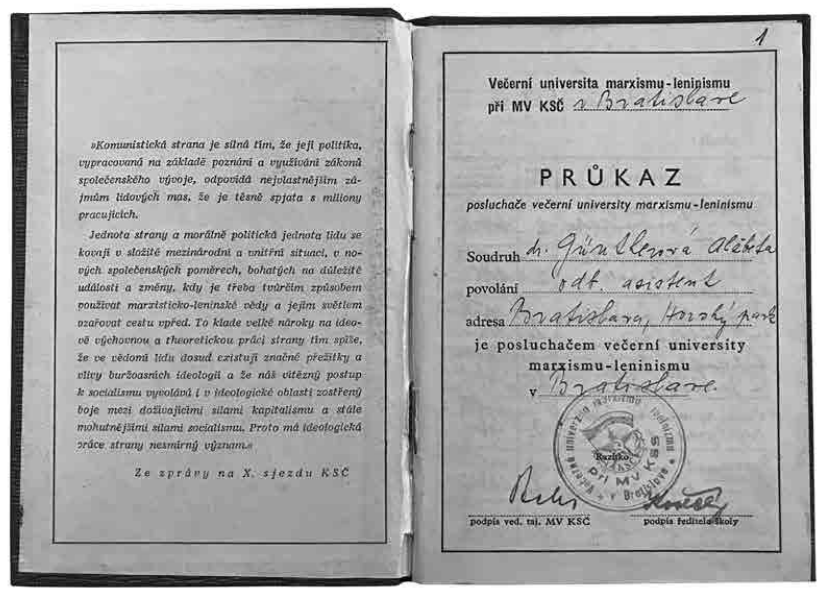

Obr. 14: Preukaz. Alžbety Güntherovej-Mayerovej z Večernej university marxizmu-leninizmu, 1958-59. Foto: ALU SNG Bratislava.

kádrových posudkov jednotlivých absolventov, ktoré musela podávat' vedeniu, cítit' nesmierne l'udský prístup, hladajúci a zdôraznujujúci pozitíva, sprevádzaný pochopením pre rôzne životné situácie, ktoré prípadne z času na čas dočasne zhoršovali prospech študentov. Práve tento l'udský a povzbudivý prístup jej, napriek početným osobným príkoriam, bol zjavne vlastný, ako to potvrdzujú aj spomienky jej absolventov. ${ }^{72}$

To sa však už dialo v zmenenom ovzduší, lebo upokojenie situácie prajúce odbornému rozvoju netrvalo dlho. V dôsledku krízy spojenej s Mad'arskou revolúciou v roku 1956 pracujúca inteligencia v Československu opät' prestala byt' chápaná ako opora režimu. Znovu prišlo na rad ostrejšie kádrovanie a zbavovanie sa nespol'ahlivých l'udí prostredníctvom politicko-odborných previerok aj v radoch komunistov. Na Univerzite Komenského začali tieto v roku 1957 ako boj proti zvyškom l’udáctva, buržoáznym ideológiám a tzv. bývalým l'udom, ktorí sa dovtedy udržali vd'aka odbornosti. ${ }^{73}$ Odbor dejín umenia $\mathrm{v}$ nasledujúcom roku prepúšt'ania $z$ práce ešte neprišiel o žiadneho zo svojich členov. Svoju

\footnotetext{
${ }^{72}$ Pozri poznámku č. 52.

${ }^{73}$ HUDEK, c. d. (v pozn. 41), s. 350-351. CAJTHAML, P. - ĎURČANSKÝ, M.: Dobové súvislosti a ohlas prověrek politické tř́dní spolehlivosti v roce 1958 na Univerzite Kar-
}

rolu v tom zrejme zohralo aj jeho nútené prevzatie zodpovednosti za čast' študentov zrušenej Vysokej školy pedagogickej. No situácia sa markantne zmenila a obete si vybrala zakrátko.

$\mathrm{V}$ týchto podmienkach dejiny umenia vedené na univerzite v Bratislave Güntherovou-Mayerovou nad’alej bojovali o pozíciu náležiacu nášmu odboru. V tézach plánu činnosti a následne v správe o činnosti za rok 1959/1960 cítit' prehíbený záujem o ideovo-politickú výchovu samotných pedagógov a prostredníctvom nich aj študentov. ${ }^{74}$ Pedagógov politicky aktivizovali prostredníctvom rôznych zadaní a funkcii. Napríklad okrem Večernej univerzity marxizmu-leninizmu navštevovanej Güntherovou-Mayerovou (obr. 14), museli na rovnakej univerzite R. Matuštík, T. Štraus a K. Kahoun absolvovat' 2 ročný filozoficko-estetický kurz. Pedagógovia navštevovali aj prednášky o ateizme, riešili aktuálne otázky dokončenia kultúrnej revolúcie a aktívne sa podiel'ali na besedách s pracujúcimi v rámci príprav Zjazdu socialistickej kultúry. Nedostatky boli konštatované v slabom ideovo-politickom vplyve na študentov, ktorý plánujú prehlbit'. V takmer rovnakom rozsahu však bola hodnotená i samotná pedagogická činnost', ako aj vedecko-výskumná a publikačná aktivita. Napokon v hodnotení malo už miesto aj sledovanie mimofakultnej činnosti pedagógov.

\section{Neželaný odchod}

Napriek nepopieratel'nému rozsahu a úspechom pedagogického pôsobenia Alžbety Güntherovej-Mayerovej na Filozofickej fakulte Univerzity Komenského bol záver 50. rokov pre ňu osobne nevel'mi priaznivý. (obr. 16) Po predchádzajúcich snahách spoločnosti o destalinizáciu a revizionizmus, došlo k opätovnej stabilizácii komunistickej moci a aj na univerzite ho poznačilo najmä oživenie politických tlakov po obnovení Novotného starších kádrových previerok. To zjavne malo dopad na neustále odklady profesorského menovania Güntherovej-Mayerovej a napokon vyústilo do jej

lově. In: Práce z. dějin Akadémie věd, roč. 2, s. 118-130. Pozri tiež GABZDILOVÁ 2018, c. d. (v pozn. 41).

${ }^{74}$ Archív KDVU FiF UK, Správa o činnosti za akademický rok
1959-1960. 


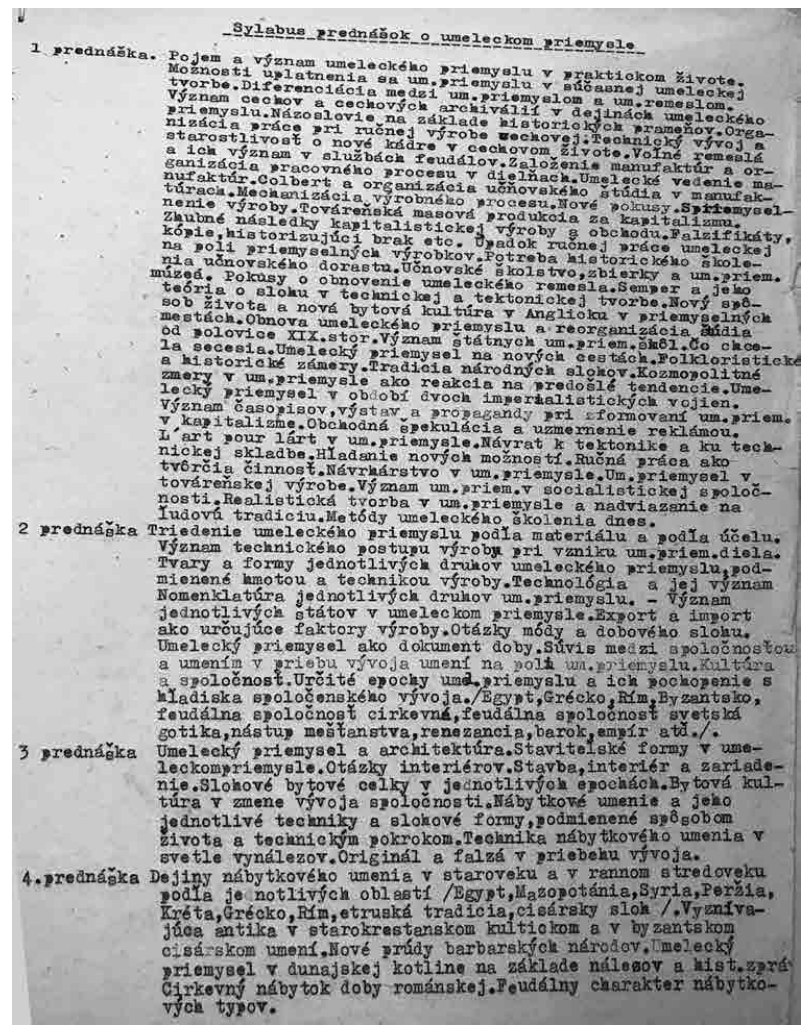

Obr. 15: Ukážka syláb Alžbety Güntherovej-Mayerovej k prednáškam o umeleckom priemysle, nedatované Foto: ALU SNG Bratislava.

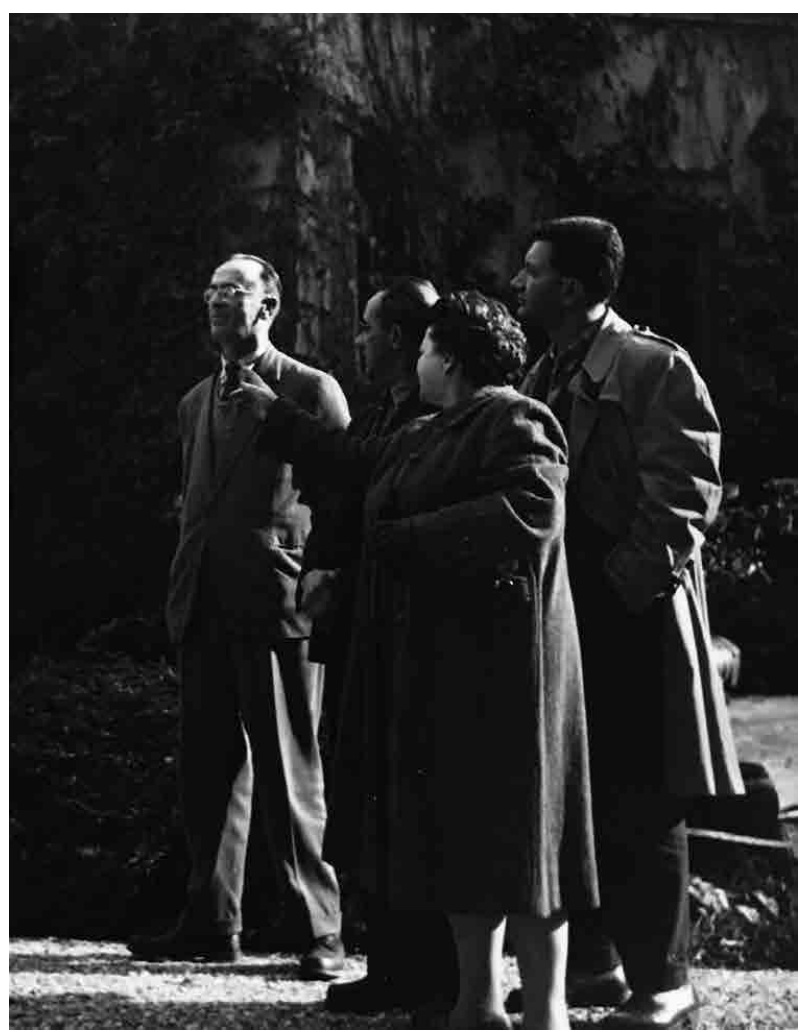

Obr. 16: Alžbety Güntherovej-Mayerovej sprevádza kolegov v Betliari (Špilda, Juhás‡, Toran), október 1960. Foto: ALU SNG Bratislava. d'alšieho neželaného odchodu z práce. V týchto podmienkach však Güntherová-Mayerová nad'alej bojovala o pozíciu náležiacu odboru dejín umenia. V závere roku 1960, za jej vedenia vystupuje suverénne Subkatedra dejín umenia už ako súčast' novej Katedry archeológie, dejín umenia, národopisu a folkloristiky. Od rozpadu Katedry vied o umení sa ešte rozšírili jej kompetencie, ked’že jej pripadla aj zodpovednost' za dobiehajúce ročníky výtvarnej výchovy Vysokej školy pedagogickej. Dejiny umenia boli na univerzite dostupné okrem denného aj ako dial'kové štúdium a Alžbeta Güntherová-Mayerová za subkatedru žiadala o umožnenie vedeckovýskumnej činnosti nielen na úrovni individuálnych plánov, ale plánov celého odboru. Rovnako žiadala

\footnotetext{
${ }^{75}$ Archív KDVU FiF UK Bratislava, Vyjadrenie k obežníku dekanátu FiF UK zo 14. decembra 1960.
}

o zriadenie vedecko-výskumného pracoviska ideálne pre samostatný odbor dejiny umenia, prípadne pre celú Katedru archeológie, dejín umenia, národopisu a folkloristiky. ${ }^{75} \mathrm{~V}$ uvedenom roku tiež prebehlo pod jej dohl'adom náročné st'ahovanie subkatedry na 3. poschodie budovy na Gondovej ulici 2 (sídlo katedry dodnes), kde spolu s E. Dubnickou mala kabinet v miestnosti č. 324. Od októbra tu naviac pôsobila aj ako zastupujúca docentka a zástupca vedúceho katedry pre otázky štúdia pracujúcich popri zamestnaní. Subkatedru vtedy tvoril okrem nej a E. Dubnickej, K. Kahoun, R. Matuštík, T. Štrauss a ako externisti J. Kostka, Marián Váross (3 hod. do týždňa k problémom československej výtvarnej moderny), Volavková a archeológ doc. Bohuslav Novotný. ${ }^{76}$

${ }^{76}$ Ibidem, List subkatedry dejín umenia dekanstvu FiF UK z 9. 6. $1960 \mathrm{k}$ prest'ahovaniu subkatedry s priestorovými 
Rozsah jej pedagogického pôsobenia bol pritom nad'alej na dejinách umenia najväčší a to 14 hodín prednášok a 7 hodín konzultácii. Čast' z nich, pre ňu príznačne úzko reflektujúca umenovednú prax s vnímaním výtvarného artefaktu ako prejavu svojej doby sa dochovala $\mathrm{v}$ jej rukopisoch.

Nasledujúci rok 1961 bol bohužial' jej posledným na Univerzite Komenského, ked'že z nej bola opät' ako politicky nespôsobilá prepustená. S nedostatočným kádrovým posudkom sa snažila zamestnat' v Prahe ${ }^{77}$ a napokon nastúpila na Pamiatkový úrad, s ktorým sa spája d’alšia dôležitá etapa jej životného pôsobenia a vznik ňou editorsky vedeného Súpisu pamiatok na Slovensku. ${ }^{78}$ Svoje sklamanie i poznačenie týmto postupom čítame v jej liste Dr. Márii Mariányiovej zo 6. septembra 1963 ku konkurzu na pedagogické miesto na Vysokej škole výtvarných umení „Súbeh konč̀ 20. sept. a som zatial' nerozhodná. Nečuduj sa, raz som na to už doplatila, mam v ₹ivej pamäti r. 1955, ked'z. univerzity deputativne ma žiadali, aby som sa vrátila ₹ Betliara, slubovali mi hory a doly a napokon (boci sa okolo mña a môjho zivota nič nezmenilo), som sa stala r. 1960 naraz kádrove brakovým tovarom. Nemám dnes u气̌ nervy a môj dobrý humor, aby som podobné sklamanie (kol'kýkrát ư̌?) prežila. To mña jedine varuje ke opatrnosti, lebo vieš, strašne rada som s mládežou a lešri mi pedagogická cimnost' ozaj na srdci, je to záruka kultúrnej kontinuity..." ${ }^{679}$ Z pohl'adu Univerzity Komenského i jej odboru dejín umenia možno len konštatovat', že v dôsledku neprajnosti režimu, individuálnych ambícii jeho stúpencov, ale i vlastnej neprezieravosti a neschopnosti chránit' svojich odborníkov prišla vtedy univerzita o mimoriadne erudovanú, všestrannú odborníčku, majúcu naviac nie len víziu, ale i schopnosti a perspektívny tím na vybudovanie silného umenovedného vedecko-vzdelávacieho inštitútu. Namiesto toho odbor čakali $\mathrm{v}$ nasledujúcich dekádach ubíjajúce provizórne riešenia s d’alšou iskierkou nádeje rýchlo zahasenou po roku 1968. V tom čase už vychádzal Súpis pamiatok na Slovensku a Alžbeta Güntherová-Mayerová napokon ako docentka učila na Vysokej škole výtvarných umení vedomá si odlišnosti umenovedných potrieb svojich tamojších poslucháčov. Zotrvala tu až do svojej tragickej smrti v dôsledku automobilovej nehody v roku 1973 (12.11.). Mala 68 rokov a rozpracovanú knihu o barokovom umení. ${ }^{80}$ požiadavkami vrátane menšej pracovne pre exernistov. Z textu je tiež zrejmé, že predtým už realizovali st'ahovanie zo Šafárikovho námestia do budovy na Kalinčiakovej ulici.

77 ŠEFČÁKOVÁ 2003, c. d. (v pozn. 3), s. 32.

78 Súpis pamiatok na Slovensku, zv. I - III. Ed.: GÜNTHEROVÁ-MAYEROVÁ, A. Bratislava 1967-1969. K jej neskoršej publikačnej aktivite okrem bibliografii citovaných v pozn. č. 41 pozri tiež GERÁT, I.: Umenie a ideológia v texte Alžbety
Güntherovej-Mayerovej. In: Stretnutie so životom a dielom Alžbety Güntherovej-Mayerovej 2003, c. d. (v pozn. 1), s. 134-143.

${ }^{79}$ Ibidem, s. 32-33 pozn. 60.

80 ŠEFČÁKOVÁ 2003, c. d. (v pozn. 3), s. 34, pozn. 65. Počas pôsobenia na VŠVU bol prijatý jej návrh na umožnenie postgraduálneho štúdia dejín umenia, pre rozširovanie aktuálnych poznatkov z konzervátorskej a praktickej výtvarnej činnosti. 


\title{
"...it is absolutely always nice to begin again..." Pedagogical Activities of Alžbeta Güntherová-Mayerová (1905 - 1973) at Comenius University in Bratislava
}

\author{
Résumé
}

Alžbeta Güntherová-Mayerová, one of the founding figures of Slovak art history, seemingly needs no introduction. The expert public has written about her turbulent life and work several times. As a result, we have biographic articles and reminiscences, case studies, as well as her classification within the context of the development of the discipline of art history in Slovakia at our disposal. Despite this, a closer look at her versatile expert activities reveals a bewildering lack of knowledge regarding certain significant phases of her work. This was also surprisingly true about Güntherová-Mayerová's long term pedagogical activities at Comenius University in Bratislava, which after WWII provided the only study of art history in Slovakia.

This article is an in-depth probe into the issues above. It is based on summarizing and verifying known, but especially new information acquired through the study of various archive sources. It strives to answer questions arising from our existing knowledge about Güntherová-Mayerovás pedagogical activities at the university in Bratislava, which affected an entire generation of our art historians. It is based on a clarification of the true extent of her work, while legitimizing the beginning of her work in the second half of the 1930s, which has been controversially presented and frequently overlooked. Thus, in the beginning, this graduate began teaching a few museologically oriented lectures at the university. These lectures continued in external form with certain adjustments until 1952. The character and extent of Güntherová-Mayerová's teaching are presented against the background of efforts to at least provisionally maintain the Seminar of Art History at the university in Bratislava during the times of the Slovak State and shortly after WWII. The analysis of a preserved manuscript of one of her lectures regarding sculpture and its techniques from 1945 provides a picture of the structure and content of her teaching.
Güntherová-Mayerovás expert pedagogical activities (among others) intensified after the war. In addition to her employment at the Department of Monument Protection of the Ministry of Education, Science and National Edification (Povereníctvo školstva, vied a národnej osvety), she lectured part-time at the Philosophical and Pedagogical Faculties of the then Slovak University (Comenius University). In 1946 she even became an associate professor at the Slovak University of Technology in fine art aesthetics. In a rapid sequence of changes in the post-war world, the political situation in our country after the revolution in 1948 was resolutely transformed. This also affected art history, whose institutional basis was broadened along with a change in understanding its role in society. During the strict period of the communist regime, striking changes related to art history at the university were taken in terms of staffing, structure, and eventually the content. The aim was to imitate the higher education system of the Soviet Union and its subordination to the state machinery.

Güntherová-Mayerová, tragically marked by the politically motivated murder of her husband, was forced to leave the university and Bratislava (1952), only to return in September 1953 due to a lack of personnel despite her stigma of political undesirability. Shortly afterwards, she finally became a full-time university employee, which marked the beginning of the most significant phase of her activities here. In the middle of the 1950s, the range of her lectures and their content from an art-historical perspective grew, and in the next six years, she was an assistant professor and the head of the section of art history, which was part of the large Department of Art Sciences. For her, this meant a path to the core of art history instruction and the possibility to enrich her lectures closely related to the material by her internationalist perception of the art-history topography and incentives from the classical Vienna School of Art History. At the same time, her 
typical orientation to accepted practical functions of this discipline allowed her to avoid the general requirements of the Marxist interpretation of art history. However, Güntherová-Mayerová played a significant role in implementing system changes in art history at the university level in Bratislava. She strengthened the significance of the discipline and the workplace itself. In addition to others, she repeatedly requested support for scientific research, which was at odds with the trend to separate research from universities. A look at this segment of her university activities also provides a picture of the character of art history in the socialist era of the Czechoslovak Republic and the tools of its Sovietization, including self-criticism of teachers, political screening, personal assessments and control and organization of outside activities.

On the one hand, this material demonstrates the significant professionalization of education in this discipline, which we have partly inherited today, accompanied by its political deformation, which unfortunately overruled in the following years. Furthermore, her forced dismissal from the university in 1961 meant losing a highly knowledgeable, universal expert with vision, ability and a team capable of building a solid art-historical scientific-educational institute. Unfortunately, she was not allowed to implement her ideas, and art history at Comenius University suffered through frustrating provisional solutions in the decades that followed. 